\title{
IMAGINING INDIA: THE NATION AS A BRAND
}

BY

SHEETAL MEHTA-KARIA

A thesis submitted in conformity with the requirements for the Degree of Arts

Graduate Department of Sociology and Equity Studies in Education

Ontario Institute of Studies in Education at the University of Toronto

(C) Copyright by Sheetal Mehta-Karia (2011) 


\title{
IMAGINING INDIA: THE NATION AS A BRAND \\ Master of Arts 2011 \\ Sheetal Mehta-Karia \\ Department of Sociology and Equity Studies in Education \\ University of Toronto
}

\begin{abstract}
This thesis critically analyzes the phenomenon of nation branding as a technique of neocolonial governmentality. The study focuses on Brand India - postcolonial India's attempt to imagine the nation and its people through the discourse of branding. I argue that India's nation branding exercise hollows out the postcolonial imagination so that the nation can now only be imagined through a language and within a framework 'always-already' constituted for the postcolony. This thesis builds on Michel Foucault's analysis of governmentality and utilizes a postcolonial framework, to show that when the practice of nation branding is applied to a postcolonial nation, it works to reinscribe the colonial legacy and reaffirm colonial power relations.
\end{abstract}




\section{Acknowledgments}

This thesis is a culmination of a difficult but nevertheless, an empowering journey. Along the way, I was guided by the intellectual wisdom and the gentle kindness of my supervisor, Dr. Kari Dehli. I began the program with a nebulous idea of what I wanted to focus on and write about. The sketchy idea became a concrete project during my independent reading course with Kari. Kari challenged me think through the questions I was struggling with and pushed me to critically reflect on the issues that I was grappling with. At the same time, she gave me the space and the support when I needed some handholding. She is a fantastic supervisor. Kari, no amount of thank yous can verbalize how grateful I am for your guidance and patience. You are awesome!

I am equally indebted to Dr. Aparna Mishra Tarc, my second reader. Aparna helped me fine tune my arguments and was always there for a quick (and sometimes not-so-quick) phone discussions. Aparna, my conversations with you always left me invigorated and ready to take on the difficult theoretical challenges. And your constant encouragement made me believe in my ability to complete this project. Thank You!

My friends at SESE were with me every step of the way. Kate Cairns - you were my mentor and you fulfilled that role splendidly! You stuck with me from Day One and continue to guide me and inspire me. Jan MacDougall - you made SESE fun for me. I miss laughing with you as we both struggled through those dense and often incomprehensible theories. Sitara Thobani -true to your name, you are a Star! You helped me think through this thesis from across the Atlantic. Your brilliance inspires me and your kindness humbles me. Shelina Kassam - no words can do justice to your contribution to this thesis and to my life. I am 
deeply grateful for your unconditional support, your daily phone calls, your reading and rereading my chapters, your sharp critique and glowing commendations. I do hope that one day, you will give me the opportunity to reciprocate.

A big shout-out to my friends outside the SESE world - Anupama Agarwal, Hiral Jhaveri, Mala Chopra, Rani Turna, Nilesha Patel, Minu Chandaria, Jadranka Culbrick-De Souza - thank you for accommodating my schedule, thank you for listening to my 'garbled' thoughts, thank you for reading my 'boring' papers, but most of all thank you for just being there for me.

This journey began on account of a gentle but constant prodding by my younger sister, Heeral Mehta Parekh. Heeral encouraged me to get back into academic life and has spent hours and hours, discussing my project with me. A big thank you to Sujay Parekh - my brother-in-law -whose thought provoking question, 'And why haven't you applied as yet?' got me going and brought me to SESE. Heeral and Sujay, thank you for bringing me back into a world that I love.

I am also grateful to my parents, Ela and Harshad Mehta for their unconditional love and support. Their faith in me never wavered even as I was losing faith in myself. Mummy and Papa - you have been with me every step of the way, nurturing me, holding me and providing me with a safe haven when everything seemed to be falling apart.

My beautiful children, Garima Mehta Karia and Amrita Mehta Karia: I love the way that your eyes lit up when I said that I had homework and I love the way that you tried your best to stay out of my way when I was trying to concentrate and finish my work. Your love sustains me and fulfills me. You have been amazing throughout this journey and I am so lucky to have the both of you in my life. 
And Amit. You have been there with me from the beginning of this journey. You took care of me throughout the way - you listened to my frustrations, you edited my papers, you took over all the household work, you managed the kid's schedules, school work and their dinners, you drove me to my lectures when I was too lazy to take the train, you put up with my short fuse and you were as excited as me when my journey finally began to take shape. Thank You for your constant thoughtfulness and unconditional love. This thesis is as much yours as it is mine. 


\section{Table of Contents}

Chapter One: Imagining India: The Introduction...............................

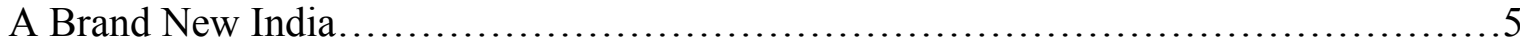

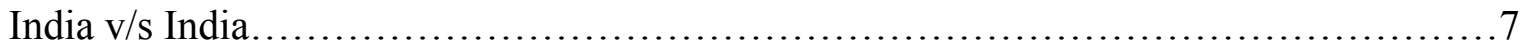

Chapter Organization............................................................ 11

Chapter Two: Imagining India: A Theoretical Framework........................13

Theoretical Underpinnings: A Postcolonial Approach..............................15

Postcolonial Studies in the Age of Globalization...................................17

Governmentality/Colonial Governmentality ....................................22

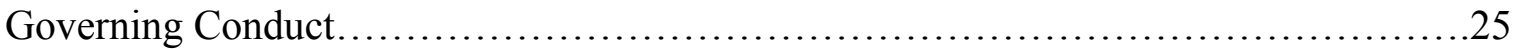

Data Collection............................................................... 31

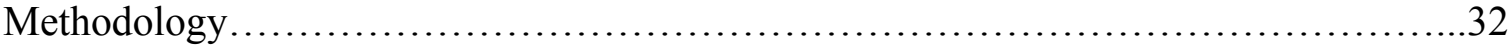

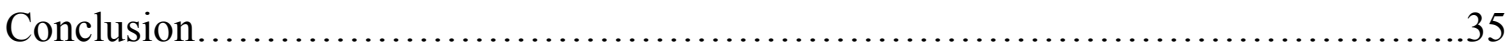

Chapter Three: Nation Branding: An Overview................................ 36

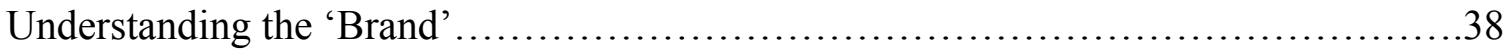

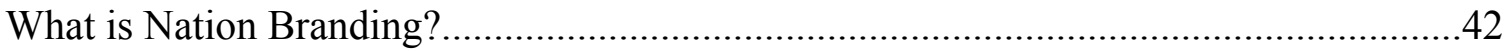

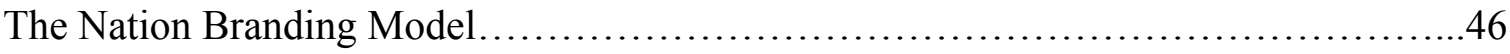

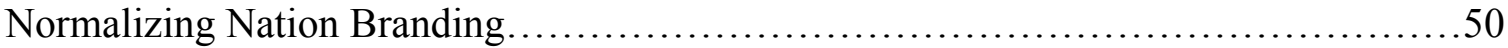

Brand Aid: Nation Branding and International Governance..........................54

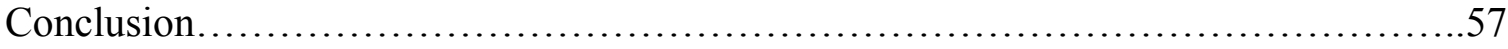


Chapter Four: Branding Nation: (Re)Colonizing Imagination.

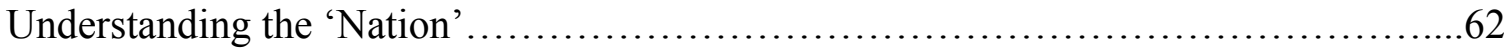

Nation Branding's economic mission......................................65

(Re)Colonizing Imagination................................................ 67

Conclusion................................................................. 75

Chapter Five: Brand India: Branding the Postcolonial Nation....................... 77

Creating the Conditions: 'India, An Idea Whose Time Has Come' ......................80

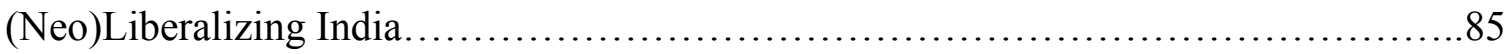

Destination Davos: 'The World's Largest Free Market Democracy'....................87

The 'Other' India......................................................... 96

Conclusion................................................................ 98

Chapter Six: Imagining India Otherwise.................................... 101

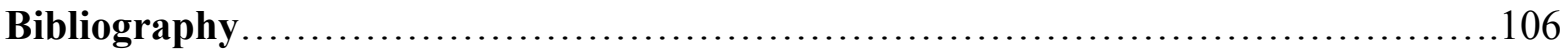




\title{
CHAPTER ONE
}

\section{Imagining India: The Introduction}

I believe India's moment has arrived. It has every making of a $21^{\text {st }}$ century miracle. In the new world, we cannot afford to ignore building Brand India. It is a commandment ${ }^{1}$.

\author{
Mukesh Ambani, Chairman, Reliance Industries \\ Member, Billionaire Club \\ Co-Chair, 2006 World Economic Forum
}

The 2006 World Economic Forum witnessed one of the most ambitious and to date, the most expensive public relations campaign launched by a nation. The snowy alpine ski resort of Davos, which for five days, each year, plays host to the most powerful and the most influential of global corporate and political elite, was transformed into the sights, sounds and colors of Brand India. Delegates arriving at Zurich airport were greeted by massive billboards, back lit in blue and white, announcing the achievements of Indian business and the nation's booming economy. Guests checking into their hotels were welcomed with gift baskets that contained among other things, pashmina shawls, I-pod shuffles with contemporary Indian music already loaded, ayurvedic bath oils and a CD highlighting India as a place in which and with which to do business. Davos attendees in mood for an evening drink were treated to complimentary 'India happy hours', wherein participating restaurants and bars featured Indian wine and culinary delicacies, prepared by Michelin star chefs flown in from London for the event (Purie, 2006).

\footnotetext{
${ }^{1}$ Mukesh Ambani was speaking at the 2003 Ad Asia Event that focused on the importance of branding India. Nearly 1,400 delegates attended the conference which discussed the need to create and steer a brand for India that would make the country relevant on the global stage (Bhushan, 2003, n.p.).
} 
As a New York Times report pointed out, 'There were few places one could go, on Wednesday, the first day of the World Economic Forum's annual meeting here, without seeing, hearing, drinking, or tasting something Indian' (Landler, 2006, n.p.). Indeed, it was difficult to ignore India that year. Apart from the billboards, gift baskets, India hour at the bar, terra cotta elephants lining the interior of the restaurants and the Indian art show, the nation's bench strength at the World Economic Forum was the highest it had ever been. With 115 high-profile delegates, participating in 200 meetings and speaking at 60 sessions (Knowledge@Wharton, 2006), the launch of Brand India at Davos conveyed the message that 'India meant serious business'.

Since the 1990s, nation branding has become a hot field for international marketing and public relations consultants. The practice involves the application of marketing and public relations techniques to create, present and project a particular image of a nation and its people for purposes of global trade and commerce. At the global level, nation branding operates as a strategy to generate and grab attention in an increasingly crowded and competitive global marketplace. With the fall of communism and the rise of globalization, more and more countries are staking claim to a finite and shrinking pool of resources. Proponents of nation branding (mainly marketing consultants and industry associates) argue that this practice allows the national governments to control and manage the message they present to the world so that they can attract the 'right' kind of foreign investments, trade and tourists. In other words, nation branding is deployed to increase the marketability of the nation in the global marketplace. As Simon Anholt, (2007), the self-appointed guru of nation branding points out, 'Just as brand management has proved to be one of the most potent instruments for devising strategy and creating wealth in the commercial sector, so its 
application to the development and competitiveness of states, regions and cities could have enormous and far reaching impacts in the years to come' (p. xii). In today's neoliberal world, it is no surprise then that countries from both established capitalist markets such as New Zealand and Britain to the newly emerging ones such as Estonia, Bulgaria, Croatia and Botswana have all launched branding campaigns.

While nations continue to jump on the brandwagon and while marketing firms find this practice an immensely lucrative line for their business (The Economist, 2006), ${ }^{2}$ the idea of nation branding is deeply contested. For Naomi Klein (2002), author, activist and a strong critic of branding, nation branding is antithetical to the essence of democracy and democratic governance. She writes, '...diversity and debate are the lifebloods of liberty. And they are the enemies of branding' (n.p.). Academic scholars have also argued that nation branding shrinks the public sphere by interpreting the nation in purely market terms (Mosco, 2001; Jansen, 2008). Others point out that this practice affects the moral basis of national citizenship since it transfers the authority to represent the nation from elected officials to branding/marketing professionals (Aronczyk, 2008). In her critique of the nation branding of the former Yugoslav states, Zala Volvic (2008) argues that branding techniques commodify the histories of these nation-states and relegate the citizens to the role of the exotic Other for the consumption of Western audiences.

While these studies do problematize the notion of the nation as a product in the global marketplace, the academic research in this area is yet to take off. As Hankinson (2001) notes, 'The branding of locations has attracted relatively little interest in the academic literature' (p.

\footnotetext{
${ }^{2}$ In 2006, Simon Anholt, the leading consultant in the field of nation branding claimed that 'one country per week' has been asking for his help (The Economist, 2006). Most large international public relations and marketing firms now offer nation branding services.
} 
139). Jansen (2008) agrees, pointing out, 'This is puzzling since nation branding is an applied communication practice that is supported by public policy and funding and encouraged by international development and trade organizations including the United Nations, World Bank, World Trade Organization and others' (p. 121). This, I believe, makes it imperative to focus on the phenomenon of nation branding and critically analyze what is it doing and what it means for the nation-state and its subjects/objects.

My thesis seeks to add to the existing literature and contribute to building of critical research in this field by situating and analyzing Brand India within a postcolonial context. I will show that nation branding is a practice that facilitates the creation of conditions that introduce, promote and naturalize 'market solutions' and 'enterprise culture' for all aspects of society - be it individual or collective, personal or national, economic or social. Furthermore, it is my contention that when nation branding operates in postcolonial nations, it does so on colonial registers, reinscribing colonial logic and propagating colonial power relations. While Brand India imagines a nation that has not only entered global modernity but is overtaking its former colonial rulers and the very economies that have labeled it a 'third world nation', it is an imagination that is informed by India's colonial past and influenced, if not dictated by the discursive frameworks of western neoliberalism. Drawing on Michel Foucault's work on governmentality, I will critique Brand India as a technology of neocolonial governance wherein India's postcolonial modernity - the contours of India's 'progress', the emergence of a 'New' India, the trajectory of its 'economic miracle' - can only be understood through the language provided by its colonial masters. I will show that neoliberalism in the postcolony is a form of neocolonialism and nation branding, a tool of neocolonial governmentality. 
I focus on Brand India, as I believe it offers an excellent example of the nation branding of a postcolonial nation that went from being perceived as 'poor' and 'developing' to becoming the focus of the global economic gaze.

\section{A Brand New India}

India has gone through many transformations since it achieved its independence from the British, in 1947. The country went from embracing socialist policies, an ethos of austerity and self imposed economic isolation for forty-five years, to becoming a poster child for globalization within a short span of ten years. Since the early 1990s, India has undertaken a massive structural adjustment program, under the watchful eye of the International Monetary Fund (IMF). India introduced economic reforms that moved the country towards privatization, ending public monopolies, removing trade barriers, deregulating industrial and trade policy and actively courting foreign investment. The liberalization of the economy saw a rise in the standard of living for a small but economically significant percentage of the population, the emergence of a middle class with strong aspirational and consumer values and a large work force of well educated English- speaking youth who were/are both professionals, ready to work for the back offices of multinationals and, consumers -ready to buy their products (Brand India, n.d.). By the mid-2000s, 'New' India, now a regular at the World Economic Forum, could lay claim to being the 'fastest growing free market democracy' in the world with an average gross domestic product of over six percent a year, ninety-one billion dollar companies and the largest number of dollar billionaires outside the United States and Russia (Holmes, 2006). 
However, this story of the transformation of India from an inward, closed economy to an open, global, market-driven economy was getting lost among the chatter at Davos. As Ajay Khanna, the CEO of India Brand Equity Foundation (IBEF), the public-private consortium behind Brand India pointed out, 'The Indian economy is doing well. We were becoming the world's back office. Our democracy is robust, yoga is globalized, Bombay Dreams ran on Broadway, Bollywood is hot, spirituality is all the rage. So why aren't we everywhere at Davos?' (Holmes, 2006, n.p.). This lack of interest in India at Davos also bothered Nandan Nilekani who at the time was the Chief Executive Officer, President and Managing Director of Infosys Technologies, India's largest information technology company and software giant. At a hotel breakfast during the 2004 World Economic Forum, Nilekani discussed this issue with other delegates, including N. Srinivasan, the then Director-General of the Confederation of Indian Industry $(\mathrm{CII})^{3}$. Their notes, reportedly written on paper napkins, went back home with them and became the foundation of the 'India Everywhere' campaign that was to take Davos 2006 by storm.

The campaign's mandate was precise - to raise the profile of India as a brand that embodied the spirit of global entrepreneurship and to showcase a nation that was all grown up with serious adults in charge, ready to talk some 'serious business'. For Ravi Aron, a professor of operations and information management at the Wharton School of Business, India in its branded incarnation was a refreshing change from the past when the nation 'blathered' on about its 'great democracy' and '5,000 years of culture'

\footnotetext{
${ }^{3}$ The Confederation of Indian Industry is a non-profit, non-government, industry led and industry-managed organization. Its primary goal is to promote India industry and Indian business by playing a proactive role in the creation of an economic environment that facilitates India's development process. For further information see, www.cii.org
} 
(Knowledge@Wharton, 2006). He was impressed that in 2006, 'They were willing to talk about ROI (return on investment) and EBITDA (earnings before interest, taxes, depreciation, and amortization)' (ibid, n.p.). Aron was not the only one to be impressed. Two years in the planning and at a cost of nearly four million dollars, the launch of the Brand India offensive at the otherwise sleepy Swiss ski resort made international headlines and India became the 'darling of the World Economic Forum' (MSNBC, 2006).

\section{India $\mathrm{v} / \mathrm{s}$ India}

This thesis aims to rupture this narrativization of India wherein the country became the 'darling' of the world's corporate elite; it also seeks to draw attention to the fact that India as imagined through the Brand is an India that valorizes particular discourses, exalts particular narratives and fetishizes particular subjectivities. Furthermore, I will show that the nation as envisioned by the brand and through the brand has become the master narrative for the country and the national subject as defined by the brand is naturalized as the norm.

This process of exalting subjectivities promoted by the brand entails the marginalizing of those that can't or won't fit in. This was evident in an editorial by the Times of India (Bose, 2007), a leading national daily and as of 2005, the world's largest selling English broadsheet. The newspaper launched an 'India Poised' campaign that pronounced 2007 as the year when Brand India would come of age (ibid). This year-long initiative was marked by a signature multi media campaign that featured Bollywood superstar, Amitabh Bachchan reciting the lyrics of the 'India Poised' anthem, penned by Gulzar, a well-known Bollywood lyricist. The advertisement, shot in soft focus and in black and white, shows 
Bachchan, dressed in a smart yet casual western suit, walking along the 'iconic', Rajiv Gandhi Sea Link ${ }^{4}$ in Mumbai, as he recites the anthem -'India v/s India':

There are two Indias in this country. One India is straining at the leash, eager to spring forth and live up to all the adjectives that the world has recently been showering upon us. The Other India is the leash.

One India says, 'Give me a chance and I'll prove myself.' The Other India says, 'prove yourself first and then maybe you'll have a chance.'

One India lives in the optimism of our hearts. The Other India lurks in the skepticism of our minds.

One India wants. The Other India hopes.

One India leads. The Other India follows.

These conversions are on the rise. With each passing day, more and more people from the other India are coming over to this side. And quietly, while the world is not looking......

A pulsating, dynamic new India is emerging. An India, whose faith in success is far greater than its fear of failure. An India that no longer boycotts foreign-made goods, but buys out the companies that make them instead.

History, they say is a bad motorist. It rarely ever signals its intentions when its taking a turn. This is that 'rarely ever' moment. History is turning a page. For over half a

\footnotetext{
${ }^{4}$ At the time of the 'India Poised' initiative, the sea link was under construction. Nearly two decades in the works, the Link is the first cable stayed bridge in the country and connects the western suburbs of Mumbai to the island city of Mumbai. It is hailed as an icon of India's commitment to progress and modernity.
} 
century, our nation has sprung, stumbled, run, fallen, rolled over, got up and dusted herself, and cantered, sometimes lurched on.

But now, in our sixtieth year as a free nation, the ride has brought us to the edge of time's great precipice. And one India, a tiny little voice at the back of the head, is looking down at the bottom of the ravine and hesitating. The Other India is looking up at the sky and saying, 'Its time to fly'. (Gulzar, 2007, n.p.)

Saying that, Bachchan nods his head, ever so slightly in the direction of the sky, decidedly turns his back to the camera and walks away with a sense of purpose, as the camera gently pans upwards towards the sky. This 'anthem' of 'New' India poses a question of identity that clearly exalts the 'pulsating', 'the dynamic' and the 'new'. The Other India is marginalized, excluded and eliminated from participating in the discourse of globalization and its attendant narratives of universalism, liberalism and prosperity. The Other continues to live in the past, held down by the leash of colonialism while 'New' India gets ready to take on the world. The 'New' India is wanted and celebrated. The Other is a burden- unwanted and expendable. India thus imagined is an example of Achille Mbembe's concept of necropolitics wherein 'the ultimate expression of sovereignty resides to a large degree, in the power and the capacity to dictate who may live and who must die' (quoted in Thobani, 2007, p.12).

While analyzing the trajectory of the nation-state as imagined through the discourse of branding, it thus becomes imperative to ask, 'what does the exaltation of the branded citizen mean for the existence and the welfare of the unbranded subject? How is it that the complex and contesting subjectivities of a billion plus citizens of the Indian nation came to 
be crystallized by a group of men over a hotel breakfast discussion? How is it that their imagination of India as a young, modern, mobile nation became the dominant narrative for the nation? What does it mean when democracy is collapsed with free market in order to make the nation more attractive to the global marketplace? What kind of subjects are invited to participate in this discourse? And, alternately, what subjects are silenced, what subjectivities obscured or erased to sustain and legitimize this discourse? Indeed, what are the 'truths' being produced and circulated through Brand India and what disciplinary practices enabled the production, circulation and normalization of these 'truths'?

I discuss these questions and engage with these conversations through a textual and content analysis of the websites that host information on Brand India. I will use the Google search engine to mine the electronic data. The keywords that guide my data collection are: Nation(al) Brand(s), Nation Branding, Brand India, World Economic Forum 2006 and Davos 2006. I also focus on the data available on the India Brand Equity Foundation (www.ibef.org) website as well as the India Everywhere website (www.indiaeverywhere.com). Both these sites host extensive information of the India Everywhere campaign that launched Brand India at WEF 2006 as well as detailed material on the brand development strategies of India's nation branding exercise. I focus on the logos, slogans, posters, brochures, videos and media reports that were a part of the promotional material for the Brand India campaign at Davos. These materials can be accessed and viewed online at the IBEF website as well as the India Everywhere website. I will also scrutinize the online media reports and representations of Brand India and the India Everywhere campaign. I focus primarily on the Indian and foreign English mainstream media reports and 
commentary, as I believe they set the agenda and the tone in circulating and normalizing the 'truths' about nation branding.

\section{Chapter Organization}

This thesis is composed of five chapters that seek to understand, analyze and critique the phenomenon of nation branding. Chapter Two lays out the analytical framework and the theoretical anchors that inform my project. I situate Brand India within the framework of postcolonialism to highlight the neocolonial legacy of the nation branding project. I also turn to Michel Foucault's work on governmentality to argue that nation branding is a technology of neocolonial governance.

Chapter Three provides an overview of the practice of nation branding. I trace the development and the institutionalization of the nation branding model as technique for economic empowerment and national wealth generation. I show how the model first developed in the West is now being offered as a 'technology-de-rigueur' for the facilitation of a developing country's entry into modernity. I discuss the normalization of nation branding as an indispensable tool, fundamental to the economic prosperity of the "newly independent' nations of the Global South who must be (re)imagined as a brand to succeed in the global marketplace.

Chapter Four argues that when nation branding is applied to postcolonial nations, it operates on colonial registers and reinscribes colonial logic. The application of the commercial practices of branding to imagine postcolonial India as Brand India, brackets the nation within a market paradigm, thereby hollowing out the national imagination to fit in with the demands of the global market and transatlantic capital. Drawing on Partha 
Chatterjee (1993), I argue that when India is imagined in a language and through a framework always-already constituted for us by the West, it (re)colonizes the postcolonial imagination.

Chapter Five draws on the various theoretical works discussed earlier, to show how Brand India operates as a technology of neocolonial governance. I begin by providing a historical background on India's liberalization program that, in effect, created the conditions for the need to brand the nation. The remainder of the chapter is then devoted to a textual and content analysis of the 'India Everywhere' campaign that was launched to make India 'credible' in the eyes of the World Economic Forum. I turn to postcolonial scholarship to show that the representation of India within the nation branding narrative, constructs a fixed nation sealed within the discursive frameworks of western neoliberalism and the Indian national identity is stripped of its complexity to project a singular corporatized subjectivity that is constituted outside of its social, cultural and economic realities.

Chapter Six revisits the key issues raised and explicated in the thesis and offers concluding remarks. It hopes to open up a space for discussion and critical inquiry and leave the readers with the reminder that while our minds may be colonized by an imagination that is structured by the dominant narratives and while 'New' India may be described in the 'Old' language of modernity, there are spaces of ongoing contestations and resistances where the nation is being imagined Otherwise. 


\section{CHAPTER TWO}

\section{Imagining India: A Theoretical Framework}

A bird -soaring upwards in flight, one wing green, the other saffron - is the metonymic mark of identification for India Brand Equity Foundation (IBEF), a public-private consortium that developed and continues to guide the brand vision for India. The choice of the bird and those specific colors is symbolic. Both the saffron and the green are part of the Indian national flag and as part of the wings of a soaring bird, they seem to represent the idea of India as a nation that is free and flying high as well as a nation that is free to fly high. As the IBEF website states,

IBEF logo seeks to symbolize India in the $21^{\text {st }}$ century.....an idea unbound.... a bird without a cage...its only canvas is the sky...limitless and expanding. The spirit of the IBEF is akin to that of a bird, forever seeking greater heights... altitude symbolizing progress....it mirrors the achievements and aspirations of a generation of Indians that is alive to global opportunities and aware of its abilities. (IBEF Logo, n.d., n.p.)

The idea to use a bird rather than a national flag or other traditional markers of national identity marks a shift in how nations have come to be represented. Explaining the shift, Wally Olins (quoted in Boxer, 2002), a nation branding consultant points out, 'Flags have nationalist, military or political connotations'. These connotations hark back to a past that is more often than not, unpleasant, conflict-ridden and painful. A bird, on the other hand, 
carries no such baggage. Instead, it conjures up images of freedom, of mobility, of endless possibilities. It is a 'postpolitical' image, as Olins puts it, that signifies a 'break from the past'.5

For a postcolonial nation like India, the desire to 'break from the past', the need for the nation to be 'unbound' and 'without a cage', is tied to the belief that its colonial and premodern past was/is the cage binding the nation, controlling it within its grip and holding India back from claiming its rightful place within global modernity. Nation branding applying marketing and communication techniques to promote a particular image of a nation - has become an active and highly visible way of signaling a break from that past and presenting a 'New' nation poised for the new global realities. Indeed, the underlying theme and the overarching message of Brand India is to present India in the era of globalization, ${ }^{6}$ as a nation that has embraced neoliberal economic policies, as a nation that has overcome its colonial legacy, as a nation that is finally free to autonomously pursue its present and its future as a global economic powerhouse, as a nation that matters within the hierarchy of nations.

While Brand India may imagine the nation as a 'bird without a cage', soaring fast and climbing high, this thesis seeks to interrogate that imaginary within the context of India's

\footnotetext{
${ }^{5}$ Wally Olins, a leading nation branding consultant made these comments in connection with Poland's nation branding exercise. Brand Poland is represented by a red and white toy kite, which according to Olins is 'joyful, modern' and takes attention away from Poland's grim past and presents it with a fresh, new persona (Boxer, 2002). I believe a similar explanation applies to the use of the bird for India's branding initiative.

${ }^{6}$ The term globalization has varied and multiple meanings depending on the context within which it is used. For the purposes of this thesis, I use the term globalization to highlight its neoliberal agenda and understand it as a 'set of processes by which the world is rapidly being integrated into one economic space via increased international trade, the internationalization of production and financial markets, the internationalization of a commodity culture promoted by an increasingly networked global telecommunications system' (GibsonGraham, 1996: 121).
} 
colonial past and its neoliberal present. The bird may represent freedom, but how is this freedom defined? Who among the billion plus Indian subjects qualifies as a citizen invited to participate in this freedom? And, while the cage may be representative of India's past, what does it mean to 'break from the past'? Or, as David Scott (1995) has pointed out, 'How is this break configured' (p. 194)?

In the sections that follow, I map out the theoretical framework and key conceptual arguments that will inform my critique of the nation branding discourse as it operates in a postcolony. I situate my analysis of Brand India within a postcolonial framework, as I believe it provides valuable theoretical tools that make visible the neocolonial underpinnings of the nation branding discourse. I also draw upon the literature on governmentality studies, in particular the works of Nikolas Rose and David Scott, to show that nation branding is a technology of neocolonial governance that promotes the myth of the sacredness of 'free' markets for economic empowerment and wealth creation. I argue that nation branding perpetuates and sustains the unequal power relationships between powerful (brand) nations of Western Europe and America and the newly independent nations, formally free, but forever branded as colonies.

\section{Theoretical Underpinnings: A Postcolonial Approach}

A postcolonial framework is useful in understanding how the nation branding discourse operates on colonial registers, reinscribing colonial logic and perpetuating a nation's colonial legacy. Postcolonial theory ${ }^{7}$ as a field of inquiry and a set of analytical

\footnotetext{
${ }^{7}$ The term postcolonial is highly complicated and deeply contested. The prefix 'post' itself complicates matters because it operates on two levels - the temporal and the ideological (Loomba 2005). In the temporal sense, the prefix 'post' operates to indicate the 'after' of
} 
approaches makes visible the structural links between past empires and the contemporary global order by drawing attention to the persistent inequities and the continuation of colonially organized geopolitical and economic hierarchies.

In his seminal book, 'Orientalism', Edward Said (2003) argues that the West or the Occident constructed (and continues to construct) the Orient and its colonized subject as poor, chaotic, infantile, immature and uncivilized, in direct contrast to the Occident's own superior subject positioning as rational, modern, civilized and mature. Said points out that Orientalism can be discussed as a corporate institution for 'dealing with' the Orient, 'dealing with it by making statements about it, authorizing views of it, describing it, by teaching it, settling it, ruling over it: in short, Orientalism was a Western style for dominating, restructuring, and having authority over the Orient' (p. 3). This positioning of a superior Occident and an inferior Orient was deployed to legitimize colonial rule and normalize Western colonialism's civilizing mission of bringing the Orient into modernity.

However, even as the civilizing mission introduced the colonized to the ideals of Western Enlightenment such as those of democracy, citizenship, freedom and civil society, these ideals were denied to the colonial subjects in practice. The colonized, it was argued, were not yet ready for them, that they were not civilized enough or mature enough to use them, that they needed more time, more education, more maturity to understand these ideals and implement them meaningfully. Dipesh Chakravarty (2000, p. 7) calls this

colonialism or subsequent to that time frame, thus invoking a clear distinction between the colonial period and its aftermath. In the ideological sense, the prefix 'post' implies supplanting the colonial aftermath, moving beyond it. Scholars such as Edward Said (2003) contest the ideological implication of the term 'post', arguing that if after colonialism, the inequities of colonial rule persist, then it is too early to claim the title of a 'postcolonial' nation. For the purposes of this thesis, I use the term 'postcolonial' in the temporal sense but align myself with the scholars who contest its ideological implications. 
developmentalist, 'first in the West, then elsewhere' mode of thinking, historicism. He points out that it was historicism that 'made modernity or capitalism look not simply global but rather as something that became global over time, by originating in one place (Europe) and then spreading outside it' (ibid: p. 7, italics in original). Historicism thus posits Europe as the center, as history's only true subject, thereby relegating the colonial/postcolonial nations to a perpetual periphery, always in the process of becoming, forever in the "waiting room of history' (p. 8).

Indeed postcolonial India, a formally independent nation for over six decades, continues to be a nation-in-progress. While during the early years of its independence, India was labeled a 'developing' nation, India in its current avatar as a brand and a poster child for globalization is characterized as an 'emerging' one. The IBEF logo of the saffron and green winged bird exemplifies this historicism. The bird that has broken from the cage of the past is still in the process of soaring, of climbing, of rising. Similarly, the western economic gaze constructs Brand India as a nation that is an 'emerging' super power, a nation 'on the road' to global dominance, a nation that is 'transforming', thus, a nation that is always in the process of becoming, but 'not yet' at the moment of arrival.

\section{Postcolonial Studies In The Age Of Globalization}

Postcolonial studies assists in highlighting the continuing hegemony of developmentalist thought - the thought that produces the West as the seat of all so-called universal ideas - within the contemporary processes of globalization. However, even as postcolonial studies draws attention to the enduring colonial logic that underlies the phenomenon of globalization, its relevance as a critical and analytical framework has come 
under sharp scrutiny (Loomba, 2005; Loomba, Kaul, Bunzil, Burton \& Esty, 2005). It has been argued that the dynamics of globalization, defined by the speed of technological and cultural exchanges and the diktats of a neoliberal economic regime cannot be understood or critiqued from within a tradition that takes as its given focal point European colonialism, its history and its legacy (ibid). The globalized world of today is marked by the fluidity of capital and a high mobility of workers, consumers, goods, industry, technology, knowledge and images across borders, thereby decentering the locations of power and dissolving traditional geographic and cultural borders. Advocates of globalization argue that this restructuring of the geopolitical conditions marks the erosion of the sovereignty of the nation-state and has resulted in the emergence of a 'new' cosmopolitanism with great liberating potential (Appadurai, 1996; Bhagwati, 2004; Appiah, 2006). Arjun Appadurai (1996) calls for a postnational approach to understanding the dynamics of globalization and points to what he calls the 'new' of globalization - 'new' patterns of consumption, imagination, communication and hybridities as evidence of the benefits of globalization especially for the developing world.

While Michael Hardt and Antonio Negri (2000) do not offer a celebratory account of globalization, they do emphasize the phenomenon as a 'fundamentally new situation' that needs to be understood, analyzed and resisted through new theoretical and conceptual approaches. Hardt and Negri argue that the integration of world markets and the velocity of cultural flows has given rise to a new form of sovereignty, wherein no single nation-state can become the center of an imperial project. They define this as the age of 'Empire' wherein, 
Empire establishes no territorial center of power and does not rely on fixed boundaries or barriers. It is a decentred and deterritorializing apparatus of rule that progressively incorporates the entire global realm within its open, expanding frontiers (p. xiii).

Hardt and Negri argue that Empire is distinct from earlier forms of European colonialism in that it has no entrenched boundaries, no competing imperial powers, no fixed margins or hegemonic cores and therefore outside the scope of the categories offered by a postcolonial framework.

However, scholars who work from within a postcolonial tradition argue that, in fact, in the age of Empire, a postcolonial approach is more relevant than ever before (Gandhi, 1998; Loomba, 2005). While the new imperial global realities may make it difficult to fix a center or a boundary, while Empire may claim to be 'outside of history', the task of postcolonial studies in highlighting the historical roots of ahistorical claims, in making visible the long history of the Empire, in examining colonial discourse and relations that make the operation of Empire possible, in identifying spaces of oppression and resistance and in learning from past anti colonial struggles, has never been more relevant, nor more urgent (Gandhi, 1998; Behdad, 2005; Loomba, 2005; Loomba et al, 2005). As Ali Behdad (2005) has argued,

The academic literature on globalization privileges the phenomena of change and novelty over those of repetition and restructuring, undermining thus the mimetically mediated nature of paradigm shifts and the interconnectedness of social orders. While 
technological advances have dramatically altered the velocity of global flow, the general structures of economic and political power do not differ that radically from their colonial counterparts (p. 69).

Furthermore, it is not just the academic world that is drawing attention to the colonially organized modern-day geopolitical order. The connections between the colonial underpinnings of the contemporary global order is also made by critics of globalization such as Joseph Stiglitz (2002), a Nobel Prize winning economist, who highlights the colonial logic that governs the modern-day, globalized, civilizing missions of transnational and multilateral organizations. He points out that,

The International Monetary Fund (IMF) often speaks about the importance of the discipline provided by capital markets. In doing so, it exhibits a certain paternalism, a new form of the old colonial mentality: 'We in the establishment, we in the North who run our capital markets, know best. Do what we tell you, and you will prosper" (n.p).

Indeed, this colonial logic of bringing the postcolonial independent states into global modernity has been termed neocolonialism by Ghanaian independence leader, Kwame Nkrumah (Ashcroft, Griffiths \& Tiffin, 2006). He argued that ex-colonizers and the newly emerging superpowers such as the United States continue to secure their hold on former colonies through supranational organizations such as the IMF, the World Bank, through 
multinational corporations and business cartels and especially through the establishment of a global capitalist economy (ibid). As Ali Behdad (2005) has pointed out,

Globalization, today, like earlier world-systems, encompasses a set of power relations articulated and mapped at different historical junctures in different, though perpetually unequal, ways. That Bretton Woods ${ }^{8}$ institutions differ from and function differently than the colonial trading companies of the nineteenth century, for example, should not blind us to the genealogical links between them that may illuminate how such managerial apparatuses enable and perhaps engender unequal development throughout the developing countries (p. 70).

Indeed, it is the engagement with the past that makes visible the impact of an inherited legacy and allows for a complex and nuanced understanding of the present. Postcolonial studies links the structures of colonial hierarchies with the marginalization and exploitation within the new world order and draws attention to the colonial context of the global flows and the neocolonial dimensions of globalization.

I thus situate my critique of nation branding within a postcolonial framework to unearth some of the asymmetrical power relations that have placed nation branding as a dominant developmentalist strategy of globalization. I question the taken-for grantedness of

\footnotetext{
${ }^{8}$ The Bretton Woods Committee was created in 1983 and is dedicated to increasing understanding of the World Bank, IMF, World Trade Organization and the regional development banks, also known as the 'Bretton Woods Institutions'. The committee is comprised of 'nonpartisan group of distinguished citizens' who also work as advisors to the above mentioned multilateral organizations and oversee and guide their efforts to spur economic growth and alleviate poverty. For further details see, www.brettonwoods.org
} 
the nation branding discourse as an indispensable technique for the facilitation of postcolonial nation's entry into global modernity. Postcolonial theory's rejection of a linear historical trajectory and its insistence on contextualizing the present in relation to the colonial past is crucial to my project wherein I highlight the neocolonial underpinnings of the contemporary nation branding discourse. The saffron and green winged bird may construct India as an 'idea unbound'. Postcolonial studies provides a framework that helps us think through how the 'idea' itself is bound by a history that has its roots in the continuing legacy of Western colonialism.

\section{Governmentality/Colonial Governmentality}

I turn to Michel Foucault's work on governmentality studies in order to understand how the practice of nation branding is made thinkable and acceptable at this particular historical moment in postcolonial India. Foucault $(1980,1984,1991)$ offers a novel understanding of the workings of modern political power. His understanding of power takes multiple forms. He moves away from thinking about power with a capital $\mathrm{P}$ - power as something that is possessed by the powerful and used to oppress and repress the less powerful into submission. Instead Foucault argues that power instantiates the subject and is something that is performed. Power refers to a set of relations that are dispersed throughout society rather than simply being vested in an individual or a particular institution such as the State or the government (Mills, 2003). In his essay Power/Knowledge (1980), Foucault writes, 
Power must be analyzed as something which circulates, or as something which only functions in the form of a chain. It is never localized here or there, never in anybody's hands, never appropriated as a commodity or piece of wealth. Power is employed and exercised through a net-like organization. And not only do individuals circulate between its threads; they are always in the position of simultaneously undergoing and exercising this power. They are not only its inert or consenting target; they are always also the elements of its articulation. In other words, individuals are the vehicles of power, not its points of application (p. 98).

In his theorizing of power, Foucault reconceptualizes the role of the individual by suggesting that modern political power does not work through coercion or by targeting the body of the individual. Individuals are not the recipients of power. Rather, they are the 'place' where power is enacted and resisted. He further argues that modern power works by targeting the conditions within which the body of the individual must live and define itself. Foucault thus focuses on the productive nature of modern power by arguing that even at its most constraining, power gives rise to new forms of behavior, rather than simply censuring the existing way of being.

Drawing on Foucault's conception of the workings of modern political power, David Scott (1995) has argued that colonial power inserted itself in the lives of the colonized by systematically breaking down the conditions within which the colonized lived and replacing them with new conditions 'so as to enable - indeed, so as to oblige- new forms of life to come into being' (p. 193, emphasis in original). The primary aim of a colonial political rationality -the structures, the projects, the targets and the numerous ways in which colonial 
power was organized and normalized in the colonies - was to produce 'governing-effects on colonial conduct' and this was achieved by creating new conditions that reconstituted the very terrain on which the colonized lived their lives. The colonized population could accept or reject these new changes; however the acceptances and the rejections could only be played out on a landscape and within a set of rules, already preconfigured for them by the colonizers. As Scott (1995) has pointed out, 'The crucial point here is not whether natives were included or excluded so much as the introduction of a new game of politics that the colonized would (eventually) be obliged to play if they were to be counted as political' ( $p$. 208: emphasis in original).

While Scott's conceptualization of a colonial governmentality interrogates the practices and modalities through which colonial conduct was governed, Nikolas Rose (1996, 1999) has shown how conduct in the age of globalization is governed through a new rationality, that of neoliberalism. Rose suggests that neoliberalism seeks to govern conduct in advanced liberal societies by creating conditions that naturalize market solutions and enterprise culture for all aspects of society. Rose (1999) writes, 'It is not a matter of 'freeing' an existing set of market relations from their social shackles, but of organizing all features of one's national policy to enable the market to exist, and to provide what it needs to function' (p. 141).

A key aspect of my project asks what happens when neoliberalism - not as a theory or an ideology but as a globally valorized set of practices for governance - is introduced in a non-advanced liberal society, in other words, a postcolony. My argument is that neoliberalism works to displace the 'old' understanding of our postcolonial present with 'new' categories, so that our modernity, our freedom, our progress, our present, indeed our 
very way of life can now only be imagined through a pre-formed language and through a set of structures 'always-already' constituted for us. Just as in the colonial era, when the colonized had no choice but to respond/adjust to the new set of rules, so also in the present neocolonial times, the postcolonial subject/s can celebrate or denounce the neoliberal conditions. However the celebrations and the dissent can only take place according to an always-already established narrative, through the categories and within a framework that is always and already constructed and constituted for them by the advanced liberal societies of the West.

Neocolonial governmentality thus operates by dismantling the existing, old forms of life and inserting new, neoliberal conditions within which the postcolonial subject must now live and define itself. In this thesis, I will show that nation branding is a practice that seeks to legitimize and naturalize the economic rationale of the western neoliberalism as a universal practice of good governance. Nation branding thus operates as a technology of neocolonial governance that reaffirms colonial hierarchies and colonial power relations.

\section{Governing Conduct}

Generally defined as the 'conduct of conduct' (Gordon, 1991, p. 2), Foucault's concept of governmentality is an analysis of who can govern, over whom and the various means through which the desired conduct can be achieved. With the concept of governmentality, Foucault moves away from identifying the state as the centre of power that controls the conduct of all citizens. He points out that the state is but one element among the multitude of techniques, strategies, programs that are deployed to effect particular responses and achieve specific targets (Miller and Rose, 1990). 'With government,' Foucault (1991) 
writes, 'it is a question not of imposing law on men, but of disposing things: that is to say, of employing tactics rather than laws, and even of using laws themselves as tactics - to arrange things in such a way that, through a certain number of means, such and such ends may be achieved (p. 95). Governmentality is, thus concerned with how power, rather than relying on coercion or prohibition, is exercised through multiple practices that 'arrange things' so as to shape, guide, modify or direct the conduct of others through calculated means.

These practices include not only the directives of state agencies and institutions but also processes of self- regulation and techniques of self-care. Conduct is directed not only through the actions of formal political institutions but also through the 'micro-technologies of everyday life' that educate, encourage and induce individuals into governing themselves and others at the 'molecular' or the local level (O’Malley, Weir and Shearing, 1997). Thus governance becomes a matter of not simply imposing or acting upon or against the individual subject or subjects, but also about inducing or 'inciting' them into a willing self governance.

Central to this understanding of government is the element of freedom and its interrelationship with thought. Foucault points out that freedom rather standing in opposition to government is in fact a resource for government. Modern power operates through freedom by structuring the field of possibilities within which the free subject is obliged to choose and act. Foucault (1982) writes, 'Power is exercised only over free subjects, and only insofar as they are free. By this, we mean individual or collective subjects who are faced with a field of possibilities in which several ways of behaving, several reactions and diverse comportments may be realized' (p. 221).

Power operates by structuring a system of thought that delineates the preferred options for possible actions and outcomes and it is within these prescribed possibilities that 
the subject is free to exercise his or her freedom. As Rose (1999) has pointed out, 'the activity of government is inextricably bound up with the activity of thought. It is thus both made possible by and constrained by what can be thought and what cannot be thought at any particular moment in history' (p. 8). This relationship between thought and government highlights the conditions under which certain things are made to be true and therefore acceptable, sayable and doable and consequently, things that are taken to be 'not true' and therefore unacceptable, silenced and undoable. Conduct thus is not shaped through the negative dimensions of power characterized by discipline and regulation; rather the focus is on the productive potential of power- how technologies of governance shape conduct by operating through thoughts and actions of the free subject.

In recent times, governmentality literature is engaged with making sense of a new regime of 'truth' that seeks to regulate conduct not just through freedom but in the name of freedom. Described as neoliberalism or advanced liberalism (Rose, 1996), this governmental regime has come to dominate most western democratic nations and operates by creating a system of thought that conflates citizenship with consumption and reconceptualizes the idea of freedom to mean 'market freedom'. Based on the post-war thinking of Ordoliberalens ${ }^{9}$ in Europe and the Chicago School of economic liberalism in the United States, neoliberal government normalizes the market version of freedom and its attendant narratives of enterprise and profit by putting into place strategies and inventing techniques that enable the rethinking of the entire social through the lens of the economic. In other words, neoliberalism propagates the myth of the market logic as the panacea for all social problems and seeks to

\footnotetext{
${ }^{9}$ The Ordoliberalens were a group of German economists and legal scholars who were associated with the journal Ordo. They argued that the role of the state must be relegated to creating policies and conditions within which the market can exist and flourish (Rose, 1996).
} 
limit government in the name of market freedom while rationalizing government in the name of that very same freedom. Elaborating on this rationale, Burchell (1993) writes,

Government must work for the game of market competition and as a kind of enterprise itself, and new quasi -entrepreneurial and market model of action or practical systems must be invented for the conduct of individuals, groups and institutions within those areas of life hitherto seen as being either outside of or even antagonistic to the economic (p. 274, emphasis in the original).

Neoliberal advocates argue that the Keynesian welfare state of the twentieth century with its emphasis on state planning, social security and state ownership of enterprises was too cumbersome to sustain. They point out that excessive state intervention had resulted in excessive government, fiscal irresponsibility, inefficient bureaucracy, lack of productivity and a culture of dependency and rigidity. According to them, the only way out of this economic and social malaise was to 'roll back' the state and 'free' the market.

Thus the state no longer exercises totalizing control over the population nor is it responsible for guaranteeing the welfare of society and its inhabitants. All state activities including those associated with traditional state function like the school or the post office are either privatized or run according to the principles of free market. However, while the state is to limit involvement with the social, it is to be actively involved in constructing the conditions - through legal, political and institutional means - that would enable the market and facilitate its functions (Gordon, 1991). Accordingly, the population is also reconceptualized as individuals, who were now constructed as autonomous, responsibilized 
actors, 'free' from the shackles of the social, ready to engage and be induced to engage in the enterprise of his or her self - the self in turn reconceptualized as a business firm (Barry, Osborne \& Rose, 1996; Burchell, 1993; Rose, 1999). Explaining this shift Rose (1999) writes,

The social and the economic are now seen as antagonistic: economic government is to be desocialized in the name of maximizing the entrepreneurial comportment of the individual. This is not a policy of economic abstentionism: on the contrary it is a politics of economic activism (p. 144).

Thus even as policy of economic abstentionism is played out as freedom from government (the idea of let the market forces 'freely decide'), the politics of economic activism has led to the invention of a whole new assemblage of practices (the argument that the state must institute reform to allow the market to function freely) for government in the name of freedom.

In this thesis, I argue that nation branding is one such technology of governance that seeks to legitimize and normalize neoliberalism in postcolonial nations such as India.

Freedom now comes to be understood through the narratives of production and consumption and the idea of national progress and development is collapsed with the tenets of economic growth. However, this thesis attempts to take this argument one step further to argue that when neoliberalism as a set of practices for governance is introduced in a postcolony, it operates as a form of neocolonialism. For, as stated earlier, when neoliberal policy reforms are introduced in a postcolonial nation, they disable the existing way of life by systematically 
dismantling the conditions within which the postcolonial lives are lived and replacing them by creating new conditions and new categories within which the postcolonial lives now must be organized. The shaping of conduct through market governance reconstitutes the postcolonial terrain by altering the narrative frame so that the "changes do not reflect a simple expansion of the range of individual choices, but the creation of conditions in which only new (i.e. modern) choices can be made' (Asad, quoted in Scott, 1995, p. 191).

For instance, the IBEF logo of the soaring saffron and green winged bird is meant to represent India as a 'free' nation. However the meaning of 'freedom' is no longer just associated with India's independence from British colonial rule. 'Free' India as envisioned by the IBEF embodies the neoliberal brand of freedom wherein India is now 'free' from the shackles of the previous socialist-democratic state to pursue its economic destiny. In the newly neo-liberated nation, the ideal Indian citizen is constructed as 'free' to consume as and how she or he chooses, to support the operation of the nation's economic freedom. The insertion of neoliberal economic reforms at the level of society itself has meant that the idea of the existential, national freedom from colonial rule is hollowed out to mean the economic freedom to consume and participate in the global economy. Ironically, the year 1991, when the 'nation broke from its (unbranded) past', is celebrated in the mainstream media as 'India's second independence' (India Today, 2003). The soaring postcolonial bird may be free to fly, but the trajectory of its flight is defined and guided by the conditions that have already been predetermined by the discursive frameworks of Western neoliberalism.

By approaching nation branding as a technology of neocolonial governance, my thesis draws attention to how this neocolonial rationality seeks to shape conduct in the former 
colonies and of the former colonies using the economic rationale of Western neoliberalism and in doing so, reinscribes colonial power relations and reaffirms colonial hierarchies.

\section{Data Collection}

My analysis is based on textual data sources on Brand India that are accessible online. I focus on the India Brand Equity Foundation (IBEF) website (www.ibef.com) that hosts extensive information on Brand India. This website is created and maintained by the Confederation of Indian Industry (CII), a consortium of public-private enterprises and is promoted as the first point of contact for those who need detailed information on India as an investment destination. The website provides detailed information on Brand India and puts on public display '(Brand) India’s amazing success story’ through films, brochures, posters, panels and the website itself. My analysis critiques how 'the successful India' is constructed through these texts and asks how these texts in turn, shape the dominant understanding of India and Indians.

I also draw extensively from the India Everywhere Davos 2006 campaign. This campaign was designed to launch Brand India at the 2006 World Economic Forum (WEF). Information and details about this campaign can be accessed at www.indiaeverywhere.com. The website hosts extensive material on the campaign itself - the promotional film/s that were screened at the WEF; the events that were sponsored by the Indian ministry and the Indian industry; the India information package; the Indian themed Davos grand soiree; the details on the India hour at the participating Davos hotels; the India art exhibit; the details on the Indian 'dream team' that led the India Everywhere initiative as well links to the press coverage and media reports about the campaign. This campaign was launched to introduce 
Brand India to the world's corporate and political elite and to make India matter within the hierarchy of nations. These texts grant an authoritative role to certain actors within the nation branding discourse and construct certain actors as ideal citizens. My analysis uses these texts to show who is constructed as the ideal Indian citizen, who has the authority to construct this ideal and the implications that this construction of an ideal Indian national citizen has for those labeled as ideal as well as those deemed 'un-ideal'.

I also use the online media representations and media reports of Brand India and the India Everywhere campaign. I focus primarily on the Indian and foreign English language reports and commentary to critique the role played by these mainstream institutions in legitimizing and normalizing the nation branding discourse.

I analyze the data by reading across these sources as they provide similar, if not identical information about India's nation branding campaign. The logos, the films, the messages collectively work to recreate the Indian nation as a brand nation.

\section{Methodology}

This thesis uses a Foucauldian method of analysis to critique the construction of Brand India as 'the' story of India. I understand discourse as a complex set of practices that 'structures what statements it is possible to say, the conditions under which certain statements will be considered true and appropriate' (Mills, 2003, p. 66). Foucault (1981) argues that discourses are historically regulated by external and internal procedures that determine what statements will be deemed intelligible and sayable and those statements that will be marginalized and erased. The external rules that govern the production and regulation of discourse are taboo (the prohibition to speak about certain subjects), the distinction 
between the speech of those classified as mad and those deemed sane and the division between truth and falsehood or the 'will to truth'.

The internal rules that regulate discourse are commentary (repeating and retelling a society's dominant narratives), the author (as an organizing principle for texts), disciplines (a grouping that determines what can be counted as knowledge within a particular subject area) and the rarefaction of the speaking subject (who can speak authoritatively on a subject). These external and internal procedures are 'all concerned with classifying, distributing and ordering discourse, and their function is ultimately to distinguish between those who are authorized to speak and those who are not - those discourses which are authorized and those which are not' (Mills, 2003, p. 58-59).

Embedded in this understanding of discourse are relations of power that determine what is taken up as true, who is authorized to speak for and about this 'truth' and how this in turn, imposes a structure on what we think and what we say. Foucault is interested in the role of these 'truths' in the shaping of conduct. He writes,

To put the matter clearly: my problem is to see how men govern (themselves and others) by the production of truth. (I repeat once again that by the production of truth I mean not the production of true utterances, but the establishment of domains in which the practice of true and false can be made at once ordered and pertinent) (1991a, p. 79).

By focusing on how 'truths' are produced through the regulatory and the exclusionary nature of discourse, a Foucauldian approach to analysis helps makes visible the connections 
between the dominant and the marginalized, the true and the false, the authorized and the discarded and the obvious and the hidden. This understanding of discourse allows us to ask the following questions: Who is entitled to speak for Brand India and consequently who is not? What kinds of statements about India are taken to be 'in-the true' and what statements are deemed false and therefore not attended to? How is it that the idea of India imagined as brand has come to be the dominant narrative at this historical moment in time? And within this narrative how is the 'ideal' Indian constructed and who is invited to take up this position and equally important, who is not?

I also approach my analysis of Brand India as a technology of neocolonial governance through the analytical lens of eventalization. Michel Foucault (1991a) has described eventalization as a 'breach of self - evidence', as a way of showing that 'things weren't as necessary as all that' (p. 76). Eventalization, as a procedure of analysis questions the taken-for-grantedness of an event and in the process seeks to make visible 'a singularity at places where there is a temptation to invoke a historical constant' (ibid, emphasis in the original). Nation branding is a practice that involves the application of corporate marketing strategies to create and project a particular image of a nation and its people for the purposes of global trade and commerce. Nation branding advocates (Anholt, 2002, 2007; Gilmore, 2002; Olins, 1999; Van Ham, 2001, 2008) argue that nations have no choice but to brand themselves if they are to compete successfully in the global marketplace. However as Foucault pointed out, it was not a matter of course that mad people came to regarded as mentally ill or that the only thing to be done to a criminal was to lock him up. Similarly, it is not 'but natural' that India should commercially brand itself to succeed in the globalized economy. It thus becomes crucial to question the obviousness of this inevitability - to ask 
how is it that Brand India has come to be constructed as desirable and natural; "to breach self evidence, of those self-evidences on which our knowledges, acquiescences and practices rest' (Foucault 1991a, p. 76).

\section{Conclusion}

In this chapter I have mapped out the theoretical framework within which I situate my analysis of nation branding. I draw upon postcolonial scholarship to argue that nation branding of a postcolonial nation such as India operates on colonial registers and perpetuates colonial power relations. I also turn to the conceptual and analytical tools offered by Michel Foucault to highlight the neocolonial underpinnings of the nation branding discourse and to underscore my argument that nation branding of a postcolonial nation operates as technology of neocolonial governance that seeks to govern conduct in the postcolony through the discursive frameworks of western neoliberalism.

While this chapter focuses on the theoretical underpinnings that inform my thesis, the chapter that follows provides an overview of the practice of nation branding. I discuss the institutionalization of nation branding as an imperative strategy for national wealth generation. I also show how the practice created and developed in the West is now being promoted and normalized as fundamental to the economic prosperity of the poor, newly independent, developing nations of the East. 


\section{CHAPTER THREE}

\section{$\underline{\text { Nation Branding: An Overview }}$}

The primary goal of Brand India - India's nation branding campaign - was to present a 'new' image of the country for the global marketplace. The 'new' image was carefully constructed to 'dismantle the negative stereotypes' associated with the country and to showcase the face of contemporary India - a face that emphasized India as an economic success story and projected the country as an efficient English speaking nation with a democratic system of governance that had embraced modern management techniques (Gentleman, 2006). Pavan Varma, director of the India Council of Cultural Relations argues that India's branding campaign was essential to change perceptions about the country, so that it could become a player of some merit in the global financial and political arena. Varma (ibid) points out,

India before was seen as an exalted exotica and the world still doesn't know much about it beyond the stereotypes, the idea of the mystic orient, its spiritual tradition. But people are making an attempt to find out about a country that is now on the radar as an economic and strategic power. Foreigners are trying to understand what India really is and what makes its people tick. (n.p.)

Indeed, nation branding consultants (for e.g. Anholt, 1999, 2002, 2003, 2007; Olins, 1999, 2002; Papadopoulos \& Heslop, 2001) argue that a national image management program is an extremely vital component of modern day statecraft. They point out in a world 
that is increasingly 'cluttered with new nations' (Olins, 1999, p. 21), a country without a strong national image and a positive national reputation will fail to reap the benefits of the current economic climate marked by an open global economy and a 'free' global marketplace. As Simon Anholt (2006), the man credited with coining the phrase 'nation brand' and the leading authority in the field of place branding has stated,

For poor and developing countries trying to compete in the global marketplace, there is no shortage of well-intentioned help and advice on offer - cash and food aid, loans, technology and skills transfer, twinning, training and resource sharing.....Yet one crucial item is missing from the list, a tool which none of the richer countries would be able to operate without, and a primary component of their remarkable economic success during the last century. This is their ability to brand (p. ix, emphasis in original).

In this chapter, I introduce the practice of nation branding. What exactly is nation branding? How does it work? What are the processes by which the commercial practice of branding a product has come to be applied to an entity as complex and heterogeneous as the nation? How is it that this practice has become naturalized as an indispensable 'tool' for the facilitation for 'poor', 'developing’ country’s entry into global modernity? India's nation branding campaign may be focused on 'telling the world good news about India on a daily basis' so as to inspire 'greater international excitement' and ultimately generate more foreign investment (Gentleman, 2006). However, by positioning the corporate practice of branding as a fundamental 'tool' for a country's economic success, nation branding as a field of practice 
and governance, universalizes the discourse of commerce and enterprise, naturalizes the processes of globalization and normalizes the myth of the market for economic empowerment and national wealth generation. In order to understand how nation branding has become a dominant narrative for 'development', 'progress' and 'growth', I begin this chapter by focusing on the term that is that at heart of this thesis: the Brand.

\section{Understanding the 'Brand'}

The American Marketing Association defines a brand as a 'name, term, sign, symbol, or design, or a combination of them intended to identify the goods and services of one seller or group of sellers and to differentiate them from those of competition' (Kotler \& Gertner, 2002). The need to differentiate the products arose with the advent of the machine age and the manufacture of products in factories. This resulted in mass production and standardization, making it difficult to distinguish one product from another. In a marketplace of similar, if not identical products, brands were created to generate an 'image-based difference' (Klein, 2000). The primary task of the 'brand image' was to give proper names to generic goods and design logos that evoked a sense of familiarity to counteract the unsettling anonymity of packaged goods (ibid).

However, the idea of the brand image as a splashy logo or a catchy slogan to 'differentiate' the product has undergone a major transformation in recent times. In the postmodern world of 'image is everything', a brand image is more about the product's reputation - how it is perceived in the minds of the consumer, what feelings and associations are linked with the product - than it is about the physical package. Naomi Klein (2000) has argued that most consumers don't truly believe that there is a huge difference between 
products, which is why it becomes important to establish emotional ties with the customers. The task of branding is to infuse the raw product with symbolic meanings and attachments that translate the act of buying into an affective experience by creating an emotional connection for the product in the mind of the consumer. These attachments conjure a feeling and create an association not with the product but with what the product as a brand has come to represent. As Scott Bedbury, author of 'Brand New World' and former vice-president of Starbucks Coffee Company points out,

With Starbucks, we see how coffee has woven itself into the fabric of people's lives, and that's our opportunity for emotional leverage.....A great brand raises the bar - it adds a greater sense of purpose to the experience, whether it's the challenge to do your best in sports and fitness or the affirmation that the cup of coffee you're drinking really matters (quoted in Klein, 2000, p. 20).

Klein argues that we now live in the age of 'lifestyle branding' so that the product that is presented to the consumer is not the 'thing' that we buy but a concept to be experienced and a lifestyle to be coveted. The experiential or the lifestyle brand attempts to resonate with the target audience by striving to make the corporate brand an integral part of their identity. Lifestyle branding is about what the product stands for, what it represent rather than what the product is used for. By 'experiencing' this product, the consumer feels a sense of belonging, of identification with others, who they know participate in a similar lifestyle. While the consumer may never meet all the millions who enjoy a morning cup of Starbucks coffee, he or she still feels a part of that imagined community - confident that there are many 
out there just like them. This sense of relating to a community through patterns of consumption and through the aspirational element of lifestyle branding, has significant impact on what the brand has come to represent in our culture and what it means in people's lives. As Wally Olins (2003) has pointed out,

\begin{abstract}
All of us who work with corporations and their brands understand that fizzy drinks, trainers, mobile phones and other apparently insignificant and entirely unmemorable trivia give real emotional and spiritual value to some lives. Many brands help to create a sense of identity, of belonging, just like the nation (p. 247-248).
\end{abstract}

However unlike the nation, a brand is created in the corporate boardroom and governed by the principles of 'consistency and coherence' so that no matter where in the world the consumer interacts with the brand, he or she is assured of the same, familiar, standardized experience. For, the hallmark of a good brand is a simplified summary. Any degree of complexity creates confusion thereby diluting the brand image (Kapur, 2003). Thus the branding mantra of 'consistency and coherence' is integrated into the very fabric of the company's corporate culture. The argument is that if the company employees 'live the brand' and the company policies reflect the promise of the brand, it enhances and strengths the brand image in the marketplace. Commenting on corporations with a tight, internal corporate culture, Klein (2000) points out,

.........Everything was an ad for the brand: bizarre lexicons for describing employees (partners, baristas, team players, crew members), company chants, 
superstar CEOs, fanatical attention to design consistency, a propensity for monumentbuilding and New Age mission statements......... These companies didn't wear their image like a cheap shirt - their image was so integrated with their business, that other people wore it as their shirt. (p. 16)

Once the corporation's head office decides upon the 'true meaning' or the 'brand essence' of the product, it is executed with 'military precision' throughout the company's operations (Klein, 2002).

Furthermore, unlike the nation, the brand is created by the corporation to serve a singular purpose - to increase the company's profit margins. A brand that consistently delivers on the promised experience adds significant monetary value to a corporation's net worth. 'Brand Equity' can be summarized as the dollar value of the goodwill generated by a strong brand. The late 1980s saw the rise of the 'brand equity mania' when Philip Morris, a company that manufactured tobacco, purchased Kraft, a food manufacturing- company for 12.6 billions dollars, six times what the company's assets and business was worth on paper (Klein, 2000). The difference was for the word 'Kraft' which carried immense goodwill and powerful brand associations. As Anholt (2007) has pointed out, ‘...one isn’t simply acquiring real estate, stock and machinery, but a trusting relationship with a segment of the marketplace' (p. 6). The purchase of Kraft foods at a record premium showed how something as intangible as a brand image with its emphasis on 'feelings' and 'experience' has a tangible effect on the company's value in the marketplace. Investing in a brand thus meant ‘investment in cold, hard equity’ (Klein, 2000). 
With the brand emerging as a lucrative profit center, that according to brand builders, added value to anything that it touches, ${ }^{10}$ it was only a matter of time before the branding community turned its attention to the enormous possibilities that civic entities such as the nation could offer (Jansen, 2008). As Van Ham (2008) has pointed out,

It is well known that the corporate brand has become an essential part of the business identity that helps audiences to identify with a company and encourages them to buy its products and services. In a similar way, branding has become essential to create value in the relationship between territorial entities and individuals. (p. 3)

\section{What is Nation Branding?}

Nation branding consultants (Anholt 2002, 2003, 2007; Fan, 2005, Olins, 1999, 2002; Papadopoulos \& Heslop, 2002) point out that as is the case with products like coffee or furniture, nations too have certain images and reputations associated with them. For example, Germany brings to mind world-class engineering; France evokes images of wine and fashion while Somalia is largely associated with war and famine. While these perceptions may be clichés or stereotypes that may or may not represent the complex realities on the ground, nation branding experts point out, they do play a crucial role in determining consumer decisions such as which product to buy and where to go for a holiday. Marketers call this the country-of-origin effect - that is, the image of the country and its reputation have an impact on the product and services offered by that country and determine their value in the

\footnotetext{
${ }^{10}$ Brand builders have argued that if water, the most basic and common of all elements can be branded and sold at a premium to affluent consumers who have access to safe, municipal drinking water, then anything can be branded (Jansen, 2008).
} 
marketplace. It is on account of the country-of-origin effect that, for example, Japanese electronics command a premium price over the ones made in Vietnam or that Turkey attracts more vacationers than Tajikistan. As Fan (2005) has argued, 'a nation's 'brand' exists with or without any conscious efforts in nation branding, as each country has a current image to its international audience, be it strong or weak, clear or vague' (p. 12).

Nation branding experts argue that in today's globalized world, the nation's brand its image and its reputation - is of crucial importance and must be managed, if the nationstate is to succeed politically and prosper economically. The integration of world markets along with increased interconnected brought about by technological revolutions has a seen a global spread of ideas, images and communities and created a new transnational order where economic processes operate above the level of the nation-state (Held \&McGrew, 2003). National governments are constantly competing with one another to attract foreign investments and tourists, to promote their exports and to gain prominence in the international political affairs and areas of public diplomacy. The challenge for economic development, thus, has gone beyond the scope of a nationally directed public policy and become a market challenge (Kotler \& Gertner, 2002). Furthermore, globalization and the harmonizing effects of integration efforts such as the Eurozone has meant that more and more nations are offering the same 'product': a business friendly national government, infrastructure, educated nationals willing to work, tax breaks for corporations, attractive cultural destinations, and a democratic system of governance (Van Ham, 2001). In such a crowded and intense environment, nation-states have to compete with each other in much the same way as corporations do, to stand out and grab the mind space of potential consumers and investors. As Van Ham points out, 
These days, individuals, firms, cities, regions, countries, and continents all market themselves professionally, often through aggressive sales techniques. Indeed, having a bad reputation or none at all is a serious handicap for state seeking to remain competitive in the international arena. The unbranded state has a difficult time attracting economic and political attention. Image and reputation are thus becoming essential parts of the state's strategic equity (ibid, p. 2-3).

Nation branding is thus the application of the principles of branding and marketing to enhance a nation's reputation and promote its image for purposes of national wealth generation. Fan (2008) has defined nation branding as 'a process by which a nation's image can be created, monitored, evaluated and proactively managed in order to improve or enhance the country's reputation among a target international audience' (p. 6). Thus the practice helps the nation-state manage and control the image they present to the world by highlighting its 'unique value proposition', achieved through consciously emphasizing a particular image of the nation and crafting a carefully managed reputation -an image and a reputation that accentuate only certain meanings and highlight only specific aspects of national identity while actively dismissing and ignoring others.

By valorizing only those aspects of national identity that are deemed desirable, nation branding is a dynamic process that reinterprets the nation for the global marketplace as well as for domestic consumption. At the global level, this strategy is meant to attract the 'right' kinds of consumers and investments, thereby leading to increased economic benefits for the nation. It also gives the nation the 'right' exposure on the international scene, making it 
easier to for it to gain access to and achieve recognition at multilateral organizations such as the United Nation, the European Union or the NATO. At the domestic level, national governments use nation branding to create a consensus for their economic policies and political decisions, and through that process invite the population to 'live' the national brand. The highly visible nature of the nation branding project - the symbols, the mainstream media coverage, the logo - is also used as a means to convince the elite stakeholders and the public that their government is acting in their best interests (Aronczyk, 2008).

While campaigns of public boosterism and the involvement of private interests in promoting the nation are age old, what is distinctive about nation branding is the normalization of the overriding logic of the market used to define every aspect of national policy - be it public or private, economic or social, domestic or foreign - so that the nation can now only be legitimately imagined through the language of the market. The architects of nation branding argue that a successful nation branding campaign is not just a communications strategy - rather it is a policy-based strategy that seeks to inform and direct every aspect of national activity. Commenting on the importance of a commercially produced but state-driven national identity program, Anholt (2007) writes, 'Just as the best-run corporations see brand strategy as virtually synonymous with their business strategy, so the best run countries should build awareness and understanding of brand management into their policy making' (p. 33). As Kaneva (2011) has pointed out, such an overt market approach to reimagining the nation and reinterpreting national identity obscures the political dimensions of national governance and erases the complexities of identity construction in order to render the nation suitable for co-option by the logic of marketing. 
By fixing the idea of the nation to fit in with the tenets of branding, the nation branding discourse valorizes neoliberalism as a technique of governance that universalizes the global marketplace. By normalizing the 'truth' that 'today, the world is one marketplace' (Anholt, 2007, p. 1), the 'tool' of branding is naturalized as leveling the playing field between the powerful brand nations of the Global North and the poor, developing postcolonial nations of the Global South, thereby recasting national wellbeing in economic terms so that a nation's progress, its growth, its development can only be understood through a language created for the market (for example, metrics and scales such as the Gross Domestic Product (GDP) that measure the efficacy of national policies) and legitimized by the market.

\section{The Nation Branding Model}

Wally Olins (2002), a British branding expert and a founding father of the nation branding movement dismisses the above-mentioned concerns as issues of semantics (the word 'brand' raises ire), snobbery (how can a nation, created by lofty ideals, be engaged in something commercial) and ignorance (that companies use similar techniques to those of nation-builders to create brand loyalty). He argues that within the current geopolitical context and globalized neoliberal system of governance, nation branding is no longer an option, it is a necessity; the issue is 'no longer whether it matters, but how to do it successfully and effectively', (Olins, 1999, p. 23).

In his book Trading Identities (1999), Olins provides a seven-step plan that a national government must undertake so that they can put into place a successful and effective nation 
branding program. According to him, a government looking to launch an identity program should:

1) Set up a working committee comprising representatives of government, industry, arts, education and the media.

2) Launch qualitative and quantitative studies to find out how the nation is perceived by its own people and by nations abroad.

3) Develop a process of consultation with opinion leaders to look at national strengths and weaknesses, and compare them with the results of internal and external studies.

4) Create a central idea on which the strategy is based with input from professional advisors. This must be a powerful simple idea, which captures the unique qualities of the nation and can be used as a base from which the entire program can be developed. The best way to do this is to prepare a page, then a paragraph, then a phrase, which may then become the dreaded strapline.

5) Develop ways of articulating the central idea visually. Designers should not just look at logos and tourist displays, but everything from the design of the airports where visitors arrive to the embassies that represent the nation abroad.

6) Look at how messages required for tourism, inward investment and export can be coordinated and modulated so that they are appropriate for each audience.

7) Create a liaison system through the working party to launch and sustain the program in government activities and to encourage supportive action for appropriate organizations in commerce, industry, arts, the media and so on. (p. 23-24) 
As this lengthy quote illustrates, the national government is at the centre of the nation branding initiative. It is the state that is responsible for ensuring that the plan is rolled out slowly and systematically and it is the state that must lead the way in projecting the new identity and coordinating the new image.

Simon Anholt (2007) also ranks state-led coordination as fundamental to a successful nation branding campaign. His theory of Competitive Identity (CI) provides a model for enhanced national competitiveness in the global world, that if 'intelligently and responsibly applied' will pay rich dividends to the member country. The CI model has identified six channels of communication that countries use to communicate with one another. They are:

1) Tourism -often the loudest voice in branding the nation as tourism promotion campaigns have the biggest budgets, are most visual and have the most competent marketers.

2) Export brands -which act as powerful ambassadors of a nation's image especially when the country-of-origin has a strong reputation.

3) Policy decisions of the country's government, whether it is foreign policy that affects populations abroad or domestic policy that is reported in the international media.

4) Inward Investments - the way the country designs its business policy to attract investments, recruit foreign talent and students.

5) Culture - Cultural activities such as the works of poets and filmmakers and cultural exchanges such as a world tour by a sports team can play a role in building a nation's reputation. 
6) People - the nation's people, how they behave when they are abroad and how they treat their visitors as well as the nation's high profile personalities all contribute to a nation's image, be it good or bad. (p. 25)

Anholt plots these 'natural' forms of communications as points on a hexagon. He argues that the CI model will enhance a nation's brand image, provided the national government plays an active role in coordinating the six channels of communication so that they send a uniform message and present a consistent image of the nation. The state plays a vital role in projecting and promoting the renewed image of the country and must liaison with the various stakeholders to ensure that the communications they send out to the world and to the domestic population coheres with the nation's brand image.

Commenting on the need for a comprehensive nation branding strategy Anholt (2007) writes,

In other words, brand management for countries should be treated as a component of national policy, not as a discipline in its own right, a 'campaign', or an activity that can be practiced separately from conventional planning, governance, economic development or statecraft.......If brand management is treated as a separate discipline from statecraft, and put into a separate silo of 'communications', 'public affairs' or 'promotion', then there is very little it can do. When, on the other hand, it becomes implicit in the way the country is run - almost, as it were, a style of policy making rather than a method in its own right - it can speed up change in the most dramatic way (p. 33, emphasis in original). 
By integrating brand management into the very fabric of national policy so as to guide every aspect of planning and strategy, the CI model operates as a tactic that contributes to creating the conditions that facilitate the imagining of the nation as a brand and as a technology that rationalizes the market version of the nation as fundamental to competing successfully in the global economy. Olins's seven-step plan for branding as well as Anholt's CI hexagon model thus work to legitimize nation branding as an ineluctable tool for wealth generation that no country in the world can do without.

\section{Normalizing Nation Branding}

Former British Prime Minister, Tony Blair's campaign to rebrand Britain, first generated mainstream interest in the practice of nation branding. Blair appointed an elite task force to refurbish Britain's image by emphasizing the country as a global hub for artistic 'cool' and promoting the nation's film, art, fashion and design. While the transformation from 'Rule Brittania' to 'Cool Brittania' was mired in controversy (Preston, 1999) and even ridiculed (Wired, 1998), it provided valuable lessons for nation branding consultants and acknowledged a political paradigm shift that recognized the importance of the "postmodern world of images' (Van Ham, 2001). While the group that worked on this campaign is no longer influential, Blair did set up the Foreign Policy Centre (FPC), a progressive think tank that published numerous white papers, organized workshops and seminars to promote nation branding and normalize the practice as an integral component of national policy and statecraft. 
It is no surprise that while most multinational public relations and advertising firms offer nation branding services, it was in London that nation branding consultants remodeled, rationalized, integrated and further developed earlier place marketing ${ }^{11}$ efforts such as the Brand Spain ${ }^{12}$ campaign and transformed a 'trial and error' approach to a full- fledged discipline with a significant body of research and writing (Jansen, 2008). The 'thought leaders' of the nation branding movement - Wally Olins and Simon Anholt - are also based out of London and work constantly to normalize nation branding as a public good. Olins is among the most vociferous supporters of nation branding. In an opinion piece for the Journal of Brand Management (2002), he responds to the 'visceral animosity' that the idea of nation as a brand provokes in people. In particular, he cites the example of Michel Girard, a French academic at Sorbonne who argues that a 'country carries specific dignity, unlike a marketed product' (p. 241) and insists that France just cannot be branded. Olins's opinion piece defends the practice by arguing that nations have always had a brand and have employed the tactics of branding for centuries. He writes,

The France of the revolution was a completely different entity from the France of the Bourbons. Not only was the traditional nobility exiled and dispersed, the royal family exiled, a republic proclaimed, religion excoriated, and an entire social and cultural system turned on its head but every little detail changed too. The tricolour replaced the fleur de lys, the Marseillaise became the new anthem, the traditional weights and

\footnotetext{
${ }^{11}$ Nation branding emerges from the discipline of marketing is situated within the subfield of 'place marketing'.

${ }^{12}$ Following the death of Franco, Spain launched a national promotional campaign to reposition the country as a modern, revitalized democratic nation. The campaign used Joan Miro's sun as a symbol to unify the various activities undertaken by the public and the private sector, to signal Spain's entry into modernity (Gilmore, 2002).
} 
measures were replaced by the metric system, a new calendar was introduced, God was replaced by the Supreme Being and the whole lot was exported through military triumphs all over Europe. You may not like the term, you may prefer to talk about a new or reinvented nation or state, but if revolutionary France was not a new brand, I do not know what is. (p. 242)

Olins's take on nation branding was integral to Tony Blair's rebranding Britain initiative and Olins was also a member of the elite group that launched the Cool Brittania campaign. Olins is also the author of 'Trading Identities' (1999), among the first documents published by the FPC on nation branding and has advised numerous countries including Poland, Germany and Liechtenstein on their image building initiatives.

Simon Anholt, the leading expert in the field of 'place branding' can be easily dubbed as the 'one-man brand ambassador' for the nation branding phenomenon. According to his website, www.simonanholt.com (n.d., n.p.), Anholt has advised governments of more than 40 countries on issues of image and reputation. These include countries from both ends of the developmental spectrum - from Netherlands, Canada, Australia, Sweden and Norway who fall under the category of 'developed' nations to Afghanistan, Bhutan, Sierra Leone and the Baltic Sea region that are categorized as 'developing' or 'least developed' nations in the world. He is a member of the Foreign Policy Public Diplomacy Board in the United Kingdom and a frequent collaborator with transnational and multilateral organizations such as the United Nations, NATO, World Bank and the EU. 
Anholt is a prolific speaker ${ }^{13}$ and apart from keynote speeches and lectures at various symposiums and conferences across the globe, he also offers 'masterclasses' - a one day or half day intensive training courses for government ministers and/or public officials that 'brings much-needed clarity, proper research, real-world experience and rigorous methodology to this important topic' (Masterclasses, n.d., n.p.). These classes are designed to help the policy makers and stakeholders grasp the importance of national identity and the need to take control of their international image. Anholt is also the author of numerous journal reports, magazine articles and books. ${ }^{14}$ He has written five major books including 'Brand New Justice' (2006) that earned rave reviews from several world leaders. A quote on the book's jacket by the prime minister of Mongolia, Nambar Enkhbayar states, 'For countries like Mongolia, which need to break into international markets, this concept provides some much needed hope and inspiration' (quoted in Anholt, 2006, n.p.). In 2002, Anholt guest edited an edition of the Journal of Brand Management that brought together perspectives from nation branding experts, consultants and practitioners. In 2005, Anholt launched the 'Place Branding and Public Diplomacy' a quarterly journal exclusively dedicated to the 'measurement, management and study of place image' (www.simonanholt.com). The journal, published by MacMillan Palgrave is the only professional and academic journal, devoted to the subject of nation branding. In 2005, Anholt also launched the Anholt-GMI Nation Brands Index, a quarterly report based on international survey data, which ranks countries according to the value of their brands, measured using the earlier mentioned hexagon model. Since then, he has also launched the Anholt-GMI Roper

${ }^{13}$ See www.earthespeak.com. The website provides a snapshot of the lectures that Anholt has given and hosts information on his upcoming speeches and keynote addresses.

${ }^{14} \mathrm{~A}$ small section of his articles and interviews can be accessed for free at http://www.simonanholt.com/Publications/publications-other-articles.aspx 
City Brands Index and the State Brands index (ibid). The results of these surveys receive widespread attention as they are regularly published in the mainstream media. For example, the Forbes magazine published a detailed report on the results of the 2011 City brands index that ranked the French city, Paris, as the overall first for city image (Howard, 2011). A Google search indicates that the same story was picked up by other news organizations too.

The nation branding discourse is also normalized by its institutionalization within the academia. Nation branding traditionally fell within the purview of the discipline of marketing. However, as indicated above, the field is gaining its own place within the academic world. Apart from a journal dedicated exclusively to the practice of place branding, there are also marketing scholars who focus on the subject. For example, Dr. Keith Dinnie (2008) is the author of the first academic textbook on nation branding, titled, 'Nation Branding - Concepts, Issues and Practice'. Nicolas Papadoulous, a professor of Marketing and International Business at the Sprotts School of Business, Ottawa, is described as a leading researcher in the field of nation branding. Furthermore, nation branding consultants regularly lecture at business schools across the world. Anholt has lectured at McGill University and the Warsaw school of Economics while Olins (1999) is a visiting professor at Lancaster University, Duxx University, Copenhagen Business School and the Said School of Business at Oxford.

The proliferation and institutionalization of nation branding indicates that the practice is now here to stay. In 1999, Olins claimed that within a decade or so nation branding will become a normal national practice. In 2011, it is safe to say that his predication has been realized. 


\section{Brand Aid: Nation Branding and International Governance}

The practice of nation branding is further legitimized by multilateral and transnational development agencies and funding institutions such as the World Bank and the United Nations, who recognize nation branding as a poverty alleviation technique. It was in 1999 that the International Finance Corporation ${ }^{15}$ (IFC), a member organization of the World Trade Organization published an opinion piece by Simon Anholt on the merits of nation branding in its journal Impact, which covers trends in global development. Increasingly, supranational economic organizations as well as regional federation such as the European Union allocate structural funding to member countries based on the country's ability to demonstrate its potential and inclination to brand itself (Aronczyk, 2008; Van Ham, 2001). Furthermore, nation branding features regularly and extensively on these organizations' agendas as a strategy to help the poor, unbranded, economically sick nations break the cycle

of poverty. For example, the International Trade Centre (ITC) (2002), a technical cooperation agency of the United Nations Conference on Trade and Development (UNCTAD) and the World Trade Organization selected 'The Values of National Strategy' as a theme for its 2002 Montreux debate. The debate also featured a discussion on 'Projecting Value — Is there a Case for National Branding? - a discussion that was later published on the ITC on-line journal (Domeisen, 2003).

\footnotetext{
15 The International Finance Corporation (IFC) is a member of the World Bank Group. It is largest global development institution that helps businesses in the developing countries generate more employment. Their goal is to create opportunities for people to escape poverty and better their lives. For more information, see www.ifc.org
} 
The World Intellectual Property Organization ${ }^{16}$ (WIPO) is also a strong supporter of nation branding (Gumbel, 2005). Simon Anholt was a keynote speaker at their international seminar in 2005 and an article based on his speech was later published in the WIPO magazine (WIPO, 2005). A report by the WIPO titled 'The Intellectual Property-Conscious Nation' (Idris and Aria, 2006) also makes the case for nation branding. The report argues,

Every country has a culture, a heritage, resources, natural beauty, and internal qualities that can be identified and defined, highlighted and captured, in a nationbranding initiative which is both pleasing and economically effective. Successful nation- branding efforts result from political will, focused national policies and strategies, and the integration of IP consideration into those policies and strategies. (p. 93-96)

In 2011, the Fourth United Nations Conference on Least Developed Countries featured an event on nation branding (UN Global Impact, ${ }^{17}$ 2011). The event titled, 'Country Branding \& Partnership: Creating and Managing Country Brand Value and Partnerships with Business' focused on how 'LDCs can create their own unique country brand enabling them

\footnotetext{
${ }^{16}$ The World Intellectual Property Organization (WIPO) is a specialized agency of the United Nations, involved with creating a balanced and accessible international intellectual property system. For details, see www.wipo.int.

${ }^{17}$ The United Nations Global Impact is a strategic policy initiative for businesses that are willing to aligning their operations according to ten universally accepted principles of in the areas of human rights, labor, environment, and anti-corruption. For more information, see www.unglobalimpact.org.
} 
to communicate a message of country-specific value, turning the country image into a valuable business asset' (n.p.)

The nation branding model is thus legitimized as a proven means of economic empowerment - a technique through which even the least developed countries can rise above their 'chaotic, backward past' and launch an image makeover program that will enhance their reputation and provide them with a potential to carve a niche for themselves in the global marketplace. As Anholt (2003) has passionately stated,

My proposal is to take this sword called branding and place it in the hands of people who actually need it and can make the best use of it. It's a good and powerful sword and in the right hands can continue to create the same miracles of prosperity for the South as it has done for the North. (preface, n.p.)

While Anholt has generously offered to share the 'sword' of prosperity with those of us in the Global South and while transnational funding agencies and multilateral aid organizations provide us with opportunities and tools to learn how to use this 'sword', it is an offer and a lesson that must be interrogated within the context of our colonial past and our postcolonial present.

\section{Conclusion}

In this chapter I have reviewed the principal ideas and the practices of nation branding as advocated by its key proponents. By tracing how the practice of branding has spread from products to nations and from the developed countries of the West to the 
developing countries of the East, I have argued that nation branding is a technology that normalizes the application of the corporate principles of branding and marketing to proactively create and manage a particular image of the nation and its people for purposes of global trade and commerce. By insisting that a successful and effective nation branding campaign must integrate the tenets of brand management into the every aspect of national policy and planning, nation branding operates to legitimize the creation of the 'competition state'.

The chapter that follows offers a critique of nation branding as a technology that locks the national imagination within the demands of the global marketplace. I discuss the idea of a 'nation' and argue that by providing a model within which a nation must be imagined so as to be considered a 'nation of reckoning' within the current geo-political order, the practice of nation branding (re)colonizes the postcolonial imagination. 


\section{CHAPTER FOUR}

\section{Branding Nation: (Re) Colonizing Imagination}

I don't even feel comfortable with this need to define our country. Because it is bigger than that. How can one define India? There is no one language, there is no one culture. There is no one religion, there is no one way of life. There is absolutely no way one could draw a line around it and say, 'This is India' or 'This is what it means to be Indian'. The whole world is seeking simplification.

Arundhati Roy (quoted in Jana, 1997, n.p.)

It was a finale that wowed the global elite at the 2006 World Economic Forum

(WEF). India's multi-million dollar 'India Everywhere' campaign, was orchestrated to break down the stereotypical image of 'old' India and reposition the country as a 'new', dynamic, business-friendly brand nation. The campaign concluded with a show stopping Grand Soiree ${ }^{18}$ that transformed the usually formal gala evening into a 'rocking' Bollywood inspired extravaganza. Close to 650 guests including Klaus Schwab, the chairman of the World Economic Forum (WEF) and John Thain, the chief executive officer of the New York Stock Exchange (NYSE) packed the Kongress Centre (Press Release, 2006c, n.p.) to attend an event that Nandan Nilekani (2006), chairman of the campaign had promoted as an 'India experience as 'real' as possible ${ }^{19}$.

The Centre, elaborately decorated with fresh Indian flowers (Sengupta, 2006)

reverberated to the sounds of the latest Indian pop music. In-demand Bollywood

\footnotetext{
${ }^{18}$ The Grand Soiree is held on the last evening of the five-day Forum and is the Forum's main social event. This was the second time that India had hosted the soiree. The first was over a decade ago.

${ }^{19}$ A month before the start of the WEF, Nandan Nilekani had sent an official letter to all the delegates, providing them with a brief preview of India' economy as well as the planned India Everywhere campaign. The letter included an invitation to attend the Grand Soiree, which Nilekani promised would be a 'memorable evening' (Nilekani, 2006).
} 
choreographer, Shaimak Davar and his youthful troupe performed against the backdrop of a giant electric blue Taj Mahal. An equally energetic performance was presented by well known Bollywood play back singer, Usha Uthup who regaled the audience with her 'foot thumping' 'multicultural and multilingual' (Singh, 2006, n.p.) musical repertoire. The high spirited entertainment was complemented by Indian haute cuisine prepared by chefs from the Taj group of hotels and paired with wines from India's premier vineyards. The evening continued well into the early hours of the morning as guests danced to the pulsating beats of club-style Bollywood music mixed by DJ Aqueel, the preferred DJ of the Indian glitterati set.

Playing host that evening was the Indian 'Dream Team' ${ }^{20}$ - a conclave of high level government ministers and bureaucrats- who continued their 'work as salesmen' (Kripalani, 2006a) pitching India as an investor friendly nation committed to trade and economic growth. The team - 'all articulate, all intelligent, all selling their country' (Zakaria, 2006)- gave much needed reinforcement to the Indian business community who used the soiree as one last sales pitch to showcase India as the preferred destination for foreign investment. Commenting on India's nation branding exercise, Aroon Purie (2006) editor of India Today magazine pointed out,

The difference with earlier attempts to promote India was stark. It would have been a few sitar performances, cottage emporium products, Doordarshan sets, classical dances. This time, it was Bollywood music and spicy food, a clear signal that India needed to, and was, changing its act and presenting the modern face of the

${ }^{20}$ The Indian Dream Team was led by Finance Minister, P. Chidambaram. The team also included, Kamal Nath, Minister for Commerce and Industry, Vasundhara Raje, chief minister of Rajasthan, Sheila Dixit, chief minister of Delhi as well as Montek Singh Ahluwalia, Deputy Chairman of the Indian Planning Commission. 
country.......With an economist as prime minister, the new hard sell of Brand India was a refreshing change, and one that could have been better timed. This was India's moment and it was obvious to anyone. (n.p)

In this chapter, I critically interrogate postcolonial India's 'moment' at the $2006 \mathrm{WEF}$ -a moment that was achieved through an intense five-day public relations campaign that was designed to 'sell' the nation in its branded incarnation to the global business community at Davos. What does it mean when a meticulously planned, carefully orchestrated, branding initiative comes to be labeled as 'the' India experience? What are the implications when that commodified, manufactured 'experience' of Brand India is promoted and celebrated as a 'real' India experience? How is it that India 'needed to' be (re)imagined in market terms so as to earn respect and gain legitimacy among the global political and business community? If gaining legitimacy as a nation that matters within the hierarchy of nations requires postcolonial India to be imagined through the nation branding model, a model that was devised and made available to us by the brand gurus of Western Europe and America, then as Partha Chatterjee (1993) has argued, 'what is left for us to imagine?' (p. 5). Indeed, what does it mean when a postcolonial nation is (re)imagined as a brand nation and national identity is reconfigured in market terms?

The transformation of India, the postcolonial nation, into India, the brand nation was deemed imperative to 'raise India's profile in the global community' (Kripalani, 2006, n.p.) and celebrated as a 'refreshing change' that presented the 'modern face of the country' (Purie, 2006, n.p.). However, it was a transformation modeled to fit within categories prescribed by the logic of the market and through a language legitimized by the market and 
for the market. By delineating the parameters within which a postcolonial nation can/must be imagined, for it be recognized as a legitimate nation in today's neoliberal world, nation branding reduces the idea of a nation to fit within the demands of the global marketplace, thereby stripping narratives about the nation off their plurality, their heterogeneity and their complexities. Drawing on Chatterjee (1993), I argue that by normalizing discussions about the nation to privilege singular conversations over diverse interpretations, by fusing the idea of a nation to the demands of capital and by delimiting our ability to imagine the nation within categories that reinscribe the colonial logic, nation branding (re)colonizes the postcolonial imagination.

\section{Understanding the 'Nation'}

The nation may be the among the most powerful historical ideas of our times, but as Benedict Anderson (1991) has pointed out, it is an idea that is very difficult to crystallize. 'Nation, nationality, nationalisms,' Anderson writes, 'all have proved notoriously difficult to define, let alone analyze' (p. 3). Hugh Seaton-Watson also laments that even as the phenomenon of nation has 'existed and exists', it is virtually impossible to come up with a 'scientific definition' to explain it (quoted in Anderson, ibid). While there are varied accounts about the provenance and the meaning of the nation, the argument in this chapter is informed by the role of 'imagination' in conceptualizing the nation.

In his influential work, 'Imagined Communities', Benedict Anderson conceptualizes the nation as 'imagined political community' (p. 6). The nation is an imagined community because, despite the inequalities and oppressions that exist within the national boundaries, the nation is still perceived as a 'deep, horizontal comradeship' (p. 7). He attributes this sense of 
nationhood, of 'fully and flatly' belonging to a larger shared community, to the socio-cultural transformations that took place during the age of Enlightenment in Western Europe. The concept of nation came into being at a time when the religious hold of Christendom was on the wane as was the aura of divinely held dynastic realms. At the same time, the rise of capitalism and its constant search for new markets, along with the development of print -ascommodity provided the people with hitherto unavailable connections of shared experiences and identity. The advent of 'print-capitalism' facilitated the publication of texts in the vernacular language and their dissemination across a vast landscape, thereby fostering notions of horizontal solidarity rather than hierarchical social groups as well as promulgating the ideas of universal national space and homogenous national consciousness.

Anderson argues that the nation is imagined because 'members of even the smallest of nation will never know most of their fellow- members, meet them, or even hear of them, yet in the minds of each lives the image of their communion' (p. 5-6). The innovations linked with 'print-capitalism' introduced a new understanding of time as a 'homogenous empty time' that could be measured by clock and calendar. This understanding of time facilitated the formation of large anonymous socialities - formed through the simultaneous experience of everyday acts such as reading the newspaper or following the lives of fictional characters in a novel. Anderson points out that while we may never meet or even know the names of millions of our fellow citizens, we are completely assured in our minds about their 'steady, anonymous, simultaneously activity' (p. 26). An individual national subject can and does feel solidarity with these unknown millions by imagining a linkage with them through, for example, the act of reading the front page of the newspaper. It is an act that is performed within the reader, 'in silent privacy', but is an act that the individual is confident is 
simultaneously performed by million others - millions whose identity will always remain unknown but whose existence is never questioned. Thus, the idea of an 'imagined' nation does not mean that the nation is 'not real' - that it is merely a figment of imagination. The distinction rejects the idea of the nation as a 'pure' and 'holistic', 'found' entity. Instead, the category 'imagination' highlights the nation as a project of ongoing construction and reconstruction, constantly being defined and redefined.

Srirupa Roy (2007) focuses on the 'figure of the state' in the production of nationhood. She argues that the postcolonial nation is produced not merely through the work of 'imagination' sustained by cultural modes of productions such as books, newspaper or art but also through the experience of repeated 'encounters' with the state - encounters that index as well as the reinforce the state as the authoritative representative of the nation. Roy points out,

While the nation is formed and sustained through the inculcation of a sense of 'horizontal solidarity' among individuals, the specification of hierarchical relations of authority between nation and state......... are of equal importance in constituting the nation as a political community.....the 'imagination of the state' and that of state -nation relations take place alongside the 'imagination of community' as the central concerns of nationalist discourse and practice. (p. 13)

Thus, for example, in post-independence, Nehruvian India, the state was imagined as the provider and caregiver of the national subject who in turn, was produced as an 'infantile citizen', in need of state tutelage and dependant on state protection. The 'encounters' with the state included public spectacles such as the Republic Day parade or massive public sector 
undertaking such as the Bhakra Nangal Dam. These encounters also include day-to-day experiences like dealing with the Indian bureaucracy and rule of law - all of which worked to reaffirm the existence of the state and to identify it as the representative of the nation. This imagination of the Indian state as the caregiver and the imagination of the Indian community as in need of state guidance has undergone a dramatic shift in recent times. As the Bollywood-inspired Grand Soiree shows, the encounter with the neoliberal Indian state of the $21^{\text {st }}$ century seeks to produce the nation through a 'market' language - Brand India- and the Indian citizens reconceptualized as ideal, neoliberal subjects, now reimagined as consuming citizens who are responsibilized for their own care and well being. This brings us to the issue at hand: What does it mean when a nation thus far imagined through cultural artefacts, is now imagined through corporate techniques of commercial branding and profit making? What does it mean when the state thus far the 'authoritative representative' of the nation looks to the private sector for setting the tone for the nation building agenda? While nation branding may be the latest form of imagining the nation that has emerged as a response to the current neoliberal world order, there are implications when state-driven nation building is explicitly underwritten by the private sector that valorizes and legitimizes only a corporatized form of imagining the nation - an imagination that does not just bracket the postcolonial nation but claims to represent the nation as a whole.

\section{Nation Branding's economic mission}

As mentioned in the previous chapter, it was in London - the former headquarters of the East India Company and the British Empire - that nation branding consultants retooled and reworked on earlier nation branding efforts and transformed a 'trial and error' enterprise 
into a 'tried and tested' model for wealth generation and economic empowerment. The architects of this practice, in particular, Simon Anholt and Wally Olins, both London-based, British branding experts argue that it was the Western nation's ability to brand their image and capitalize on their reputation that made 'rich countries rich' (Rendon, 2003). They argue that economic wellbeing of the newly independent nations of the Global South is dependant on their ability and their willingness to undertake a cohesive and comprehensive national identity program As Olins (1999) has pointed out,

Countries with a chaotic, wretched or turbulent past which are attempting to emerge with a new social, political, industrial, commercial and cultural persona must eventually realize that in order to be noticed in the world at large, and to be assisted in the process of change, rather than lumped together as bunch of corrupt, useless self destructive basket cases, they too will have to take active steps to create a positive identity....... If they don't launch such programmes it will be increasingly difficult to attract assistance. It will be increasingly difficult for them to help themselves and they will remain trapped in a morass. (p. 21-22)

The presentation of the practice of nation branding as a model to emulate and follow for the 'new' nations of the Global South constructs the poor, postcolonial nations as 'nations in need' while simultaneously positioning the rich, colonizing nations of the Global North as 'nations in the know'. This elevated positioning of the West by the nation branding discourse reinforces the colonial hierarchy of nations, thereby reinscribing the colonial binary of Superior West and inferior East and perpetuating the myth of the western (economic) 
civilizing mission. Anholt (2003) has proposed the handing of the 'good' and 'powerful' sword of branding to the Global South so that they too can use it to experience the 'miracle' of economic 'prosperity'. Just as the colonizing mission of the British empire was rationalized as a means to bring the uncivilized natives into modernity, so also must nation branding - a technology, geo-politically conceived by transatlantic powers, be 'given' to the 'poor, backward, chaotic' countries. Nation branding thus repeats and perpetuates the (neo)colonial civilizing mission of bringing the postcolonial nations into economic modernity.

\section{(Re)Colonizing Imagination}

The 'offer' of the nation branding model with its a predetermined script for development and a predesigned trajectory of progress - a script and a design created by our former colonial masters - does raise specific issues of concern. The offer for 'prosperity' and economic empowerment comes in a language and through a framework 'always-already' constituted for us by the West and legitimizes only a particular way of imagining the nation - an imagination that is bound by market expectations and locked with the neoliberal version of development and progress. If we in the postcolonial world must imagine our nation through this 'always-already' constituted model of nation branding, so that we can gain legitimacy as a nation, so that we can rise above our chaotic past, so that we can begin our journey towards prosperity, then as Partha Chatterjee (1993) has pointed out, 'our imaginations must remain forever colonized' (p. 5).

Chatterjee makes this remark in response to Benedict Anderson's (1991) claim of the Eurocentric roots of nationalism. Anderson argues that nations were (and are) being 
imagined into existence in Europe as well as all over the world. However, he posits that it was European nationalism that provided the rest of the world with universal/standardized ideas of nationality and nationhood. Anderson points out that nationalism is a cultural artefact of a particular kind that once created through discrete historical forces of the eighteenth century became 'modular' and therefore easily transferable to other 'social terrains' irrespective of their political and ideological associations. Thus, according to him, it was the historical experiences of nationalisms in the West, in particular Western Europe and America, that supplied subsequent anti-colonial nationalists in the Global South with the modular forms of nationalisms, from within which they could choose what they deemed was best for them.

Chatterjee rejects Anderson's claim, arguing that Anderson's attempt to universalize the Eurocentric idea of an imagined nation, denies the postcolonial world our imaginations, our resistances, our nationalisms. Chatterjee writes,

If nationalisms in the rest of the world have to choose their imagined community from certain 'modular' forms already made available to them by Europe and the Americas, what do they have left to imagine? History, it would seem, has decreed that we in the postcolonial world shall only be perpetual consumers of modernity. Europe and the Americas, the only true subject of history, have thought out on our behalf not only the script of colonial enlightenment, but also that of our anticolonial resistance and postcolonial misery. Even our imaginations must remain forever colonized. (1993, p. 5) 
Here, Chatterjee draws attention to the fact that the Indian anti-colonial struggle was marked by difference rather than identification with the 'modular' forms of western nationalisms. Colonial India had its sovereign domain even before it began its political battle for independence. According to Chatterjee, this was achieved through the separation of the social institutions into two domains: the material or the outer domain and the spiritual and the inner domain. The material domain was the realm of economy, science and technology where the Indian nationalists acknowledged the superiority of the West and emulated it. The spiritual domain, on the other hand was where India preserved its distinctiveness, its cultural and spiritual authority. This domain thus became a site of contestation and a realm where the colonial state was denied access.

As Chatterjee points out, it was here, in the realm of the spiritual that the antinationalist nation emerged. He writes,

In fact, here nationalism launches its most powerful, creative and historically significant project: to fashion a 'modern' national culture that is nevertheless not Western. If nation is an imagined community, then this is where it was brought into being. (1993, p. s6)

Chatterjee's critique of Anderson's universalizing claims of nationalism draws attention to the colonial underpinnings of the nation branding discourse. Nation branding consultants discursively construct the practice of nation branding as the only way out of economic misery and geo-political isolation for the unbranded South, thereby normalizing the western capitalist formulations for success and of success. By positing the Western practice of corporate branding as the authority and therefore the 'right way', the 'only way' 
or the norm, nation branding constructs the unbranded nations - the countries deemed as possessing a 'chaotic, backward and wretched past' - as 'immature nations in need for guidance' and 'nations to be saved'. For example, the successful launch of Brand India at the 2006 WEF led the former chief of the WTO, Panitchpakdi Supachai to remark, 'Just five years ago the India reception attracted 50, maybe 60 people. But look at it now! India is doing so well, it does not need our help anymore' (quoted in Kripalani, 2006a, n.p.).

This construction of a 'nation in need of our help' erases the root cause of the need for 'help' - centuries of colonial oppression marked by plunder, famine, slavery, war, genocide - and diminishes the misery inflicted by years of sustained social, political and economic exploitation. The nation when imagined as a brand is evacuated of its contentious history and its violent past at the hands of the colonial and now Western neocolonial powers, to present a fresh face for the global marketplace. The Eurocentric nation branding model is normalized as a preferred technique for wealth generation and is constantly valorized as a tool of economic empowerment that can level the playing field between the Global North and the Global South. However, the model posits that for a poor, backward nation to make its mark on the global stage, it must be reimagined through the language of capital and within the framework of western neoliberalism. By legitimizing success in the marketplace as the only way out of economic sickness, nation branding denies the postcolonial nations their way of imagining their development, their prosperity and their success. For example, it was only after the launch of Brand India at Davos - the imagining of the nation in brand speak and market talk - that Ajay Khanna, the chief executive officer of the India Brand Equity Foundation (IBEF), saw a 'new respect for India' in the eyes of the those that matter at the WEF (Knowledge@Wharton, 2006). 
The infantalization of the newly independent nations of the South as nations that must look to the brand gurus of the West for tutelage and the branding model for guidance produces the postcolonial nations as the economic Other and marginalizes their version of progress, their version of modernity, their formulations of success. For example, the First World economies and transnational aid organizations such as the International Monetary Fund deemed India's economic model of 'welfare state' as responsible for the countries slow pace of growth and progress (Tripathi, 2006). Nation branding thus reinscribes colonial power relations and reinforces the colonial hierarchy of nations. Furthermore, by lumping all postcolonial nations into a single, monolithic category of 'unbranded States' or 'developing nations' or 'emerging economies', nation branding erases the multiple and diverse histories of their colonial oppression and flattens the complexities of their colonial aftermath.

The reinscription of the colonial logic is evident in postcolonial India's nation branding exercise. Brand India imagines the nation through the colonial binary of the modern (material realm) and the premodern (spiritual realm). India when imagined as a brand celebrates the material realm, covets its modernity and emulates its neoliberal agenda. The Brand India initiative was launched at the $2006 \mathrm{WEF}$ to present the country as an attractive destination for foreign investment, as an emerging manufacturing hub and as a credible partner for world business - a nation thus imagined was bound by its ties to the market and fused with the demands of capital. The Brand India film clip on 'Imagination' (Brand India Films, n.d., n.p.) exemplifies the dominance of the market narrative on the Indian imaginary. The clip was produced as part of a 'holistic nation messaging campaign' to project the idea of a 'resilient and resolute' India - a nation that can withstand any economic challenges and a nation that it firm in its resolve to emerge as an economic superpower. The thirty seconds 
clip features Nandan Nilekani, the CEO of Infosys and the architect of the India Everywhere campaign. The sprawling, 43 acre Infosys campus in Bangalore with its lush green lawns and pyramid shaped futurists glass paneled structures serves as the backdrop for film. The film is essentially a montage of images that showcase the very modern infrastructure of the company, the very orderly employees and the very manicured grounds, interspersed with close shots of Nikelani talking to the camera. Outlining the role of imagination in facilitating India ascent on the world stage, Nilekani tells the viewer,

In a country where aspirations are unleashed, it is critical to provide people with access.

Access to education. Access to capital.

And then they will find their own access to opportunity.

Often we limit ourselves to what we see and not what we imagine.

Let us remember that the imagination of a few can transform the life of millions. Imagination is the new raw material of vision. (n.p.)

The short clip ends with a shot of the Brand India logo and an voice over that proudly announces the tag line: India. It happens here. The clip is reminiscent of the Infosys success story. The company was founded in 1981 by seven software engineers who used their 'imagination' to realize their 'vision' of transforming a small software company into a billion dollar global corporation. As Nilekani claims, the imagination of seven has transformed the lives of millions including their employees, their suppliers, their customers, those who take inspiration from their story, those whose imaginations they support through 
their investments and those whose imagination they mentor through their educational programs, so on and so forth.

However, 'imagination' as envisioned, understood and promoted by Nilekani is an imagination that is hollowed out so as to serve the logic of the market - it is an imagination that is locked with the demands of capital and not allowed to be realized outside of it. An ideal (brand) imagination is an imagination that naturalizes the unrestricted movement of capital across time and space and normalizes its attendant narratives of growth (gross domestic product), progress (return on investments), prosperity (market capitalization) and market freedom (privatization and deregulation). Any form of imaginings that restrict the flow of capital in the time of 'here' and 'now' are discarded as something that is pre-capital or belonging to the pre-modern, and eliminated as something that does not belong and should have been left behind. By constructing imagination as a 'raw material' for economic success and by confining its interpretations within market determined classifications, nation branding hollows out the category 'imagination'. It does so by emptying it out of its pluralities, thereby denying recognition to what Chatterjee (1993) has called 'our modernities'.

By imagining the nation through the empty homogenous time of capital ${ }^{21}$ where acts of political economy such as jobs, salaries and the unrestricted flow of capital play a role in creating an imagined community, nation branding fixes the idea of the nation within the language of the market and locks the national imagination within the narratives of production and consumption, thereby (re)colonizing the postcolonial imagination.

\footnotetext{
${ }^{21}$ Marxism would call the homogenous empty time, the time of capital as it is the same simultaneity that allows us to imagine a nation through the act of reading a newspaper, also allows us to imagine the nation through acts of political economy such as jobs, market, salaries and so on. For a detailed discussion see Partha Chatterjee (2005).
} 
While the material realm is emulated by the postcolonial nations, the spiritual realm is imagined as the old and the premodern, encapsulating a past that impedes the advance of modernity and the free flow of capital. It is therefore a past that must be done away with. The only way the premodern can exist as part of the branded imagination is if it can be redefined and reimagined to serve the modern. For example, the ancient Indian practice of yoga lends itself to commercialization and is therefore allowed to participate in the Brand India discourse because of its marketability and profitability. The ancient Indian science of medicine - Ayurveda - also features prominently within the Brand India narrative. However it is packaged not as a remedy for ailments but as a holistic beauty treatment for the body, mind and soul. The Indian state of Kerela, marketed as 'God's own Country' is a hot tourist spot for Ayurvedic spas and cleansing retreats. The branding discourse also co-opts cultural and religious sites that can be repackaged as 'heritage' destinations for tourists.

Nation branding thus legitimizes a singular conversation that serves the needs of capital and the demands of the marketplace. By privileging the material over the spiritual, the modern over the premodern, the old over the new, the present over the past, the particular over the diverse and the homogenous over the multitudinous, nation branding commodifies the public imagination and hollows out its pluralities so that the only legitimate way of imagining the nation is through the language of the market and for the market. The offer to give the postcolonial world a 'sword to fight their economic miseries, is also an offer that perpetuates the colonial misery and prolongs the colonial aftermath. 


\section{Conclusion}

The evening of January $28^{\text {th }}, 2006$ marked the occasion of the grand soiree at the WEF. This time it was sponsored by India - the brand New India. As the crowds danced to the tunes of the latest Bollywood tunes, Nandan Nilekani watched with pride. The architect (2008) of the India Everywhere campaign later commented,

This was the finale of the 'India Everywhere' campaign, a Confederation of Indian Industry (CII) and India Brand Equity Fund (IBEF) initiative to put Brand India on the world map. I had conceived the idea and orchestrated its roll out with the enthusiastic support of India's biggest entrepreneurs. As the crowd danced to a vibrant Bollywood beat, it was clear that a new India was being showcased, which was young, confident, diverse and entrepreneurial. (p. 149).

In this chapter I have argued that the presentation of India as a 'young, confident, diverse and entrepreneurial' Brand Nation points to the failure of our collective postcolonial imagination to think outside the Eurocentric model of development and progress. The application of the corporate techniques of branding to imagine the nation brackets the nation within a commercial paradigm, thereby hollowing out the national imagination to cater to the demands of the marketplace. While Bollywood beats and crowded dance floor may put India in its manufactured, branded incarnation on the world map, it is a version that recolonizes the postcolonial imagination by denying us a language through which we can articulate 'our modernities'. 
In the chapter that follows, I provide a textual and content analysis of 'Brand IndiaThe World's Largest Free Market Democracy' - to show how Brand India is a technology of neocolonial governance that constructs India, the nation, in market language and constitutes Indians through narratives of consumption and production. 


\section{Chapter Five}

\section{Brand India : Branding the Postcolonial Nation}

For the first time in its history, Independent India took center stage at the World Economic Forum (WEF). The 2006 annual meeting of the world's global and political elite at Davos, was abuzz with the 'New India Story'- the story of a 'democratic' nation wedded to the ideals of 'free' market. At the time, India was clocking an average growth rate of over six percent annually (the rate has gone up since then and is pegged at $8 \%$ for the year $2010-2011$ (PTI, 2010, n.p.)) and the Indian economy had more than doubled in real terms over the past decade. Consumer demand was growing three to five times faster than the economy and a young, ever-expanding middle class with strong consumer and aspirational values was providing the country with an added impetus (Nilekani, 2006). 'It is a good time to be in India', wrote Nilekani (ibid, n.p.) in a letter to the 2006 Davos delegates and invited them to participate in the 'New India Story'.

The frenzied interest in India at Davos 2006 was no accident. It was created by design through an expensive and elaborate public relations and marketing campaign that put 'Brand India on the world map' (Nilekani, 2008, p. 149). The campaign's core message showcased a democratic country that was an attractive destination for foreign investment and lucrative partner for world business. This message was constantly and consistently relayed across the various Forum events to ensure that the 'New India Story' stayed top of mind for the global audience.

The overall theme for Davos 2006 was 'Creative Imperative' and India was featured as one of the sub-themes for the five-day event. Sessions on India included discussions on the 
'Emergence of India' and 'New Energy for India Reforms' (Kripalani, 2006a). Also discussed was the 'India-US partnership' as well as 'India and the World: Scenario 2025' (Press Release, 2006, n.p.). There was also an Indian speaker at 60 of the conference's 300 sessions (Knowledge@Wharton, 2006). High profile Indian business and government officials worked the Davos crowd round the clock to reinforce the 'New India'. The country's 'soft' power was also on display with India themed cocktail hours, and Bollywood inspired soirees. The appointment of Mukesh Ambani, chairman of Reliance Industries as the co-chair of the conference complemented the spectacular events as did Lakshmi Mittal's audacious multi-billion dollar bid for Luxembourg-based Arcelor steel company- a bid that was made during the five-day summit. As Ajay Khanna, the chief executive officer of the India Brand Equity Foundation (IBEF) and a key player of the 'India Everywhere' campaign pointed out,

The entire flavour at Davos was India - hearing India, tasting India, and smelling India. We wanted to project it as the fastest growing free market democracy in the world. India with its capabilities is now roaring, with not just BPO (Business process outsourcing), but also EPO (Engineering process outsourcing) and KPO (Knowledge process outsourcing). It is also a strong manufacturing hub. The overall theme at the forum was that of 'credible' India. (quoted in Holmes, 2006, n.p.)

In this chapter I examine the construction of 'credible' India through the country's nation branding project - Brand India. I provide insight into the conditions that created the need to brand the nation and highlight the tactics and rationalities that made it thinkable and 
practicable to reimagine India as a brand nation. I approach nation branding as a technology of neocolonial governance that seeks to shape conduct in the former colonies and of the former colonies using the economic rationale of western neoliberalism. The construction of Brand India for and under the western economic gaze produces a nation that is hollowed out of its complexities and its heterogeneities, so as to enable its easy co-option within the logic of the market and the demands of global capital.

I analyze Brand India through a collection of texts produced by the agenda setting institutions and authorities - both governmental and private - that work to recreate and legitimize the 'truth' about an 'ideal' India and 'ideal' Indians. My analysis is based on the following sources of data: 1) The IBEF website (www.ibef.org) that hosts extensive promotional and brand development material on Brand India. 2) The India Everywhere campaign website, www.indiaeverywhere.com, that provides detailed information on the launch and the execution of the Brand India campaign at the $2006 \mathrm{WEF}$ and 3) The online media representations and media reports of Brand India and the India Everywhere campaign. I work across these various websites and numerous reports/documents to analyze the construction of India and Indians through the nation branding discourse. I view nation branding as a field of discourse that produces and governs the imagination of India as a brand and in the process, highlight some of the inclusions and exclusions that discursively constitute this postcolonial nation as a brand nation.

I engage with these texts through the analytical lens of eventalization, in order to question the taken for grantedness of the nation branding discourse as 'the' fundamental strategy for growth and progress of a postcolonial nation. I further situate my critique within the postcolonial framework to discuss how the brand representations of India and the Indian 
national identity is flattened so as to project a singular entity/subjectivity, constituted outside of the social, cultural and economic realities.

Creating the Conditions: 'India, An Idea Whose Time Has Come'

On July 24, 1991, India’s finance minister, Manmohan Singh stood before the lower House of the Indian parliament and presented a budget that changed the Indian nation forever. India's economy to date had followed a Soviet style, state -led central planning model that favored a closed trade policy and heavy reliance on state intervention. The Indian government focused on a policy of import substitution that meant reliance on internal sectors for development rather than international markets (Varshney, 2007). Furthermore, the centralized nature of planning was governed by licenses and quota systems that determined what was produced, in what quantities and at what price. The closed economy and tight governmental controls meant that the Indian economy remained stagnant at a growth rate of $3.5 \%$, also dubbed as the 'Hindu rate of Growth',22 (Tripathi, 2006).

During the 1980s the government borrowed heavily from international agencies to support a stalling economy that had become reliant on public spending for generating growth. Between 1980 to 1991, India's domestic public debt had jumped from 36 percent of the Gross Domestic Product (GDP) to 56 percent and its external debt had tripled to nearly $\$ 70$ billion dollars (Independent Evaluation Group, n.d). The volatile fiscal situation was compounded by internal political turmoil and external factors such as the collapse of the

\footnotetext{
22 The phrase 'Hindu rate of growth' was coined by Indian economist Raj Krishna to indicate the sluggish pace of India's economy - a country with a predominant Hindu population who are supposed to be fatalistic and content in their demeanor. While a 3.5\% growth may be desirable by European standards, it is considered low and unhealthy for country of India's size (Tripathi, 2006).
} 
Soviet Union and the rise of the Asian 'tiger' economies. Furthermore, there was a steep increase in oil prices on account of the 1991 Gulf War (The Economist, 2011). The substantial increase in the cost of oil imports along with the corresponding decrease in foreign exchange earnings caused an 'unprecedented' balance of payments situation for the country wherein India had only enough foreign exchange reserves to last a fortnight (Singh, 1991). That, combined with a sharp decline in capital inflows resulted in the downgrading of India's credit worthiness and consequent weakening of international confidence in the Indian economy. With the country at the brink of economic disaster, India was forced to airlift 47 tonnes of gold to the Bank of England as a collateral for loan, while it waited for more aid from the International Monetary Fund (IMF) (The Economist, 2011). As the finance minister (Singh, 1991) told the members of the parliament,

There is no time to lose. Neither the government nor the economy can live beyond its means year after year. The room for maneuver, to live on borrowed money or time, does not exist any more. Any further postponement of macro-economic adjustment, long overdue, would mean that the balance of payments situation, now exceedingly difficult, would become unmanageable and inflation, already high, would exceed limits of tolerance.......We do not have time to postpone adjustment and stabilization. We must act fast and act boldly. (p. 2-3)

The 'fast' and 'bold' actions of the finance minister included a comprehensive economic liberalization program that came to be known as India's New Economic Policy (NEP) and introduced a neoliberal economic regime in postcolonial India. The NEP was 
initiated as a direct result of a $\$ 500$ million IMF- World Bank loan - a loan that was authorized under the aegis of an IMF-World Bank structural adjustment operation and stabilization project (SAP). The loan came with provisions that stipulated aggressive market reforms. The SAP is characterized by policies of fiscal austerity and monetary contraction on one level and deregulation of labor/financial markets and removal of trade barriers on another level. The role of the state is severely curtailed as it is believed that central planning and state intervention are the root cause of inefficiency and poor output. The SAP reforms thus involve the privatization of state and parastatal organizations, reduction in public expenditure and reduction or elimination of subsidies in social and public sectors. It is important to note that the retreat of the state from society does not mean degovernmnetalization per se (Barry et al, 1996). Rather, under the neoliberal system of governance marked by the dominance of market logic, the role of the state is reconfiguredthe state must now focus on putting into place policies that allow for the creation of conditions within which the market can exist and thrive. As Barry et al (1996) have pointed out, 'Neo-liberalism, in these terms, involves a less a retreat from governmental 'intervention' than a re-inscription of the techniques and forms of expertise required for the exercise of government' (p. 14).

Thus the implementation of SAP in India meant that the Indian state thus far a 'compassionate state' had to be reconfigured as a 'competition state' and the Indian economy thus far closed and protectionist, had to 'open up' by adopting market friendly legislations. Accordingly, the 1991-92 budget introduced far- reaching market reforms that 'rolled back the state' by dismantling the existing trade structures and economic policies and replacing 
them with a liberalizing trade regime that eased restrictions on foreign investment and opened up the Indian market to international competition.

Among the key market reforms introduced by the budget was the liberalization of the policy regime for Foreign Direct Investments (FDIs) by raising the limit for foreign equity to 51 percent in high priority industries and granting these acquisitions prompt approval (Singh, 1991). The budget also abolished the complex quotas and licensing systems, thereby freeing up business and industry to pursue their goals, unfettered and unencumbered by the demands of the Indian bureaucracy. Furthermore, the budget scaled back government expenditure, allowed mutual fund investments of up to twenty percent in key public sector industries, introduced deregulation and privatization in the domestic sector and ended public sector monopolies on a whole range of industries such as oil and gas and telecommunications (ibid).

Within weeks of implementing the NEP, the government devalued the rupee by 23 percent and introduced a market determined exchange rate, raised interest rates, cut import tariffs, revised the 1991/92 budget, made sharp reductions in subsidies and funding to public enterprises and introduced measures to strengthen capital markets and institutions (Independent Evaluation Group, n.d.). Singh (1991) ended his speech to the parliament by commending the NEP and seeking endorsement from the members for the economic reforms. He declared,

.....As Victor Hugo once said, 'no power on earth can stop an idea whose time has come'. I suggest to this august House that the emergence of India as a major economic power in the world happens to be one such idea. Let the whole world hear it loud and clear. India is now wide-awake (p. 31). 
In the following section, I elaborate on the sudden awakening of India from decades of economic slumber and its dramatic effect on Indian business and society.

\section{(Neo)Liberalizing India}

The effects of the reforms were felt almost immediately. With the finance minister rolling up the red tape of Indian bureaucracy and rolling out the red carpet for business (Nilekani, 2008), India managed to avert its immediate balance of payment crisis and improve its creditworthiness. The Hindu rate of growth became a thing of the past, with the Indian economy now on an upward swing, growing at the rate of 6 percent in 1994-95 and over nine percent from 2005 to 2007 (The Economist, 2011). Foreign investment began to flow into the country and grew from $\$ 100$ million in the 1980 s to $\$ 300$ million by $1992-93$ and was expected to cross the $\$ 10$ billion mark by 2007 (Varshney, 2007). India's trade-toGDP ratio more than doubled in 2006 from its 1991 level of 15\% (ibid) while Indian exports increased by over 12 percent, along with a huge surge in foreign exchanges reserves that quadrupled over projections (Independent Evaluation Report, n.d.).

The NEP 'unleashed' an 'atmosphere of entrepreneurship' by easing license restrictions, access to credit and eliminating controls on capital and interest rates. For instance, with the elimination of wealth tax, money that was locked in steel cupboards at home found its way into the stock market and enabled a whole new generation of entrepreneurs who could now tap into capital markets and compete across industries (Nilekani, 2008). Furthermore, India's manufacturing and service sector began to play a key role in the economy and India's world-class information technology sector grew 
exponentially, producing 5\% of the nation's GDP (Varshney, 2007). As Nilekani (2008)

pointed out,

When I think of India's entrepreneurial shift, I see it as a fundamental change in our attitudes towards competition, moving from the mindset of the Bombay Plan, when companies clamored for state coddling and protectionism, to the Bombay Club, when they continued to demand trade barriers, to finally the tradition of Bombay House, where Indian businesses have become outward looking, unafraid of competition and willing to take risks and enter new markets, targeting India's so-far untouched, rural country and the world beyond our borders. (p. 81)

Indeed, the pace of the reforms was opposed by the big Indian business houses that were fearful of foreign competition and used to the protectionist regime of the Indian state. With the implementation of the NEP, Indian businesses had no choice but to adapt and respond to the changing economic climate.

The shift in economic policy did not just change the way business was done in India. It also changed the Indian mindset towards production and consumption. The Indian economic boom saw the emergence of a new Indian middle class, numbering between 250 million to 300 million (Varshney, 2007). The middle class, thus far known for its financial conservatism was beginning to 'discover the joys' of consumerism. As Sheetal Mafatlal, a member of one of India's oldest industrialist families, who brought the luxury Italian brand Valentino to India, points out, 'As an entrepreneur, I identified that our lifestyle is changing. 
We are on the upward curve of a retail boom although the market is still not a mature market' (Betts, 2006, n.p.).

Indeed, the upward swing meant that in 2006, more than six million cells phones were sold in India every month, making it the fastest growing cell phone market in the world (Hebbar, 2006). As an editorial in the Times of India (ibid) pointed out, by the end of 2006, an estimated 450 malls were expected to open doors in the top six cities of the country. The Indian car market was growing at a rate of 10 percent and more than million cars were sold in 2004-2005. By 2005, there were 16 million credit card holders and the Indian retail market was valued at $\$ 30$ billion dollars. As Hebbar (2006) proclaimed, 'India is rocking thanks to a middle class that is turning out to be the largest consumer in the world' (n.p.).

While the policy reforms and the attitude shift was celebrated by the mainstream media and the Indian elite, it had still to register impactfully with the three thousand decision makers who descend upon Davos each year. India continued to be at the periphery of this global summit with discussions primarily revolving around the issue of outsourcing. The Indian business elite decided it was time tell Davos a 'fuller, richer story about India's emergence as an economic power' (Holmes, 2006). As Nilekani (2006) pointed out,

Today India's appeal stretches from Wall Street to Broadway, from Capital Hill to Cannes. Policymakers, economists, businessmen and Journalists - all are univocal in their opinion - India is Everywhere. The prevailing global environment and sentiment towards India presents a unique opportunity to secure disproportionate attention towards India, from the global business and political communities alike. The 
time to leverage this opportunity is now. (Press Release, 2006, n.p., emphasis in original)

Brand India was thus launched with full fanfare at the 2006 World Economic Forum to capitalize on the India's economic momentum. In the section that follows I analyze how the construction of Brand India as the 'World's Largest Free Market Democracy' reimagines a nation that conforms to the norms of the market and reproduces Indians within a language that valorizes market metrics and market terminology. I critique the conflation of the ideas of 'democracy' and 'freedom' with the 'market' and show that India thus imagined is primarily for the benefit of global capital.

\section{Destination Davos: 'The World's Largest Free Market Democracy'}

The India Everywhere campaign at Davos was built on three key pillars: India's vibrant democracy, India's growing consumer market and India's promise of assured returns for the global investor (Press Release, 2006a, p. 3). However, the Indian market and the promise of good returns were underscored by the emphasis of the campaign on India's democracy. Indeed, it was India's 'Vibrant Democracy' that became the 'unique selling proposition' or the USP of Brand India. As guests and delegates arrived at Dock A of the Zurich airport, they were greeted by a huge blue and white billboard that stated in bold, capital letters: INDIA, WORLD'S LARGEST FREE MARKET DEMOCRACY, with a tagline: 8\% GDP growth in July-September 2005 (Media Outdoor, 2006, n.p.). This message was also displayed on taxis, buses and bus shelters across Davos to ensure a high and a constant visibility for 'democratic' India. As a New York Times report pointed out, 
'Advertisement on buses here promote India as the 'fastest-growing-free-marketdemocracy'- a not so subtle reference to China, which has done little to relax the grip of the Communist Party over society. By contrast, India is a clamorous democracy with 675 million eligible voters' (Landler, 2006, n.p.).

Rather than downplaying the 'clamorous' nature of the Indian democracy, the campaign highlighted its 'compliant' nature by indicating that India's domestic political upheavals were inconsequential to the country's commitment to liberalization and trade reforms. As the delegates left the customs check at the Zurich airport and arrived outside Dock A, they were greeted with another billboard that emphasized India's trajectory of growth and its espousal to the tenets of neoliberalism. The billboard proclaimed: 15 years, 6 governments, 5 prime ministers, ONE DIRECTION, with a tagline that stated: $6 \%$ average annual GDP growth (Knowledge@Wharton, 2006).

The message highlighted the fact, that despite the frequent change in governments, one thing remained constant - India's commitment to neoliberal practices of governance and the upward trajectory of India's economic growth. The message was meant to assuage the anxieties of global capital that prefers a stable government and a steady society. It assured 'big business' that there was consensus among India's policy-making elite, irrespective of their political and party affiliations or the mandate of popular vote. For example, during the 2004 general election, Indian voters ousted the ruling Bharatiya Janata Party (BJP) and rejected its India Shining ${ }^{23}$ campaign to vote the United Progressive Alliance (UPA) into power (Bidwai, 2007). The UPA had campaigned on the promise of inclusive growth and

${ }^{23}$ 'India Shining' was the political slogan of the Bharatiya Janata Party (BJP) and used during the 2004 election campaign to capitalize on the feeling of economic optimism in India. Subsequent to the election, the phrase has come represent the westernization, modernization and commercial development of certain segments of Indian society. 
slowing down the pace of market reforms. However, once in power, the UPA government with Manmohan Singh as the new prime minister, continued the pace of reforms ${ }^{24}$ and further privatized the infrastructure, allowed foreign investment in education and reduced taxes on luxury goods (ibid). As Varshney (2007) has pointed out,

Whatever coalition comes to power, reforms on the whole will continue. Since 1991, four coalitions have ruled India and none has departed from the path of reform. The differences have been more of degree and pace, not direction. (103)

Thus while India's democracy is showcased as the USP for the brand nation, it is a watered down version of the original - democracy-lite- diluted to serve the needs of global capital and demands of the global marketplace, thereby undermining the very essence of the word, democracy. The role of democracy within the Brand India narrative is constructed to facilitate India's entry into the global markets and conversely to smoothen the entry of global capital into India. The India Information Pack (2006), designed to give the Davos delegates an overview of India's 'booming' and growing market economy, proudly lists the nation's democracy as a 'source of competitive advantage' (p. 4). The glossy package devotes five pages to India's 'Vibrant Democracy' and provides brief snap shots of the nation's democratic institutions such as the parliament, the independent judiciary, the constitution, the media and the country's massive electorate. While these institutions may be showcased as

\footnotetext{
${ }^{24}$ The UPA government did pass three progressive parliamentary acts - Forests Rights Act that gave forest dwellers the right to their land; Right to Information Act and National Rural Employment Guarantee Act (NREGA) that guarantees every rural family a hundred days of work at minimum wage. However, the government simultaneously continued to institute market reform (Roy, 2009).
} 
symbols that define Indian democracy, they are celebrated for providing the ideal backdrop in facilitating a 'growth model' that creates 'more efficient corporates, healthier banks, more robust services and larger consumption base' (ibid, p. 5).

Indeed, it is India's 'Vibrant Democracy' that is deployed to provide the Indian brand with the added sheen, giving it a dazzle needed to attract attention in a marketplace crowded with other brand nations. However, the commodification of the Indian democracy and its conflation with market enterprise serves to erase the very 'vibrancy' that the campaign so proudly proclaims. Klein (2002) reminds us that democracy by its very nature is complex, messy and fractious - the antithesis of a brand. By streamlining the essence of democracy, by restricting its meaning(s) and by constraining its function(s) to singularly facilitate the 'ease of doing business' (India Information Pack, 2006, 4), the Indian democracy is stripped of its contestations and its complexities, rendering it futile and irrelevant within the context of the Indian electorate. As Arundhati Roy (2009) has pointed out,

The question about life after democracy is addressed to those of us who already live in democracies or countries that pretend to be democracies.....It is meant to suggest that the system of representative democracy - too much representation, too little democracy, needs some structural adjustment. (n.p)

Indeed the Indian 'Dream Team', comprising key government officials and top business leaders underscores Roy's argument of 'too much representation and too little democracy'. The team worked in close unison, hosting dinners, addressing plenary sessions and conducting closed doors meetings to project a consistent image of India by emphasizing 
the competitive advantage of a 'compliant' Indian democracy. 'Democracy is a big advantage for us,' said Malvinder Singh, president of Ranbaxy Laboratories, India's biggest pharmaceutical firm (Landler, 2006), while Nandan Nilekani, chairman of the campaign asserted the compatibility between a democratic system of governance and economic growth stating, 'India will achieve 8\% growth this year as a democracy' (Kripalani, 2006a). Their message was reaffirmed by India's 'democratically' elected representatives - who, as mentioned earlier, had won the right to represent the Indian people, on the promise of inclusive growth. However, at Davos, Indian officials 'shed the Gandhi cap and the rhetoric of serving the nation' (Kapur, 2006) and went to work as 'salesmen', marketing democratic India as an ideal place in which and with which to do business. On the last day of the conference, finance minister, P. Chidambaram addressed a packed breakfast meeting, in a session, titled 'Audience with India’s key policy makers' (Press Release, 2006b, n.p.). The meeting was attended by global CEOs including Peter Barbeck-Letmanthe, CEO of Nestle SA, Andrew Crockett, President, JP Morgan Chase International and Kaven V Watts, Chairman, Merril Lynch International (ibid). Chidambaram assured these brokers of transatlantic capital that India remained committed to free market reforms and that the government was focused on pursuing policies that facilitated capital investments and greater freedom for foreign direct investments. Thus, it is through market control and economic dominance that the (neo)colonial project is kept alive in postcolonial nations who are now required to corporatize their national image (India Inc.) and commodify their national identity (Brand India), so as to remain relevant within the new economic order. As Kapur (n.d.) has pointed out, 
The symbiosis between state and commerce at the World Economic Forum at Davos in 2006 where the $\mathrm{CII}^{25}$ put up an India Everywhere campaign to market India's culture, market and labor force; putting everything up for sale. For a country, whose memory of throwing out the British Empire is as recent as 1947 and kept alive in a generation whose children and grandchildren are being socialized as subjects of another Empire, to sell the nation is a travesty and betrayal of the honest and heroic sacrifices of several generations who won India its freedom. (n.p.)

However, the Brand India narrative that has come to dominate the neoliberal Indian imaginary has co-opted the idea of 'freedom' and reimagined it through the lens of the economic. Within this context, freedom is no longer associated with India's independence from centuries of British colonial rule and freedom struggle is no longer characterized by India's nationalist, anti-colonial movement. Neoliberalizing India is focused on 'market freedom' - the fight to break free from the shackles of post independence India's socialist policies and the struggle to escape the tyranny of a restrictive trade regime that kept a tight grip on business and growth. Freedom thus reconceptualized is articulated through the narratives of production and consumption wherein India is now 'finally free' to pursue her economic destiny and the Indian citizen is 'finally free' to consume as per his or her choice. The 1991 liberalization project was hailed by the Indian mainstream media and the ruling Indian elite as 'India's second independence' (India Today, 2003) that finally ended the 'incomplete' freedoms granted by 'India's first independence'. As former Indian prime

${ }^{25}$ CII stands for the Confederation of Indian Industry. It is a industry-led and industry managed organization that works to create and sustain an environment conducive to growth of industry in India. For further details see www.ciionline.org. 
minister, P.V.Narasinha Rao, whose government initiated the process of liberalization in India proudly proclaimed, 'the full freedom to dream the way you like came only in 1991, not 1947 (quoted in Nilekani, 2008, 148).

The Brand India narrative exemplifies this sentiment through its promotional video 'India: fastest growing free market democracy' (Brand India Films, 2006, n.p.) - that was specifically created for Davos 2006. The video consists a montage of images that represent the neoliberal understanding of the words that make up its title. The moving images are accompanied by a fast, upbeat, fusion soundtrack that blends the sounds of a tabla (Indian drum) with other western instruments, while a male voice threads together the various notes of an Indian raga in a fast tempo. The images flash on the screen at a break -neck speed - to signify a nation celebrating its 'full freedoms' and to symbolize a nation in haste, rushing to make up for lost time, racing to fulfill its economic destiny. When the word 'Freedom' appears on the screen, it is accompanied by a visual of a young girl who, it appears, can barely contain her joy at being 'fully free'. She is shown smiling, standing at her windowsill, looking upwards, towards the sky as the wind blows in her face. This shot of a young girl dreaming of endless possibilities is tagged with the phrase, 'living every dream'. The next set of images portray off-shore oil drilling plants and huge, modern factory floors- images meant to symbolize a 'free' and open economy. Another set of images are tagged with the phrase 'welcoming the global brands' and the logos of McDonalds, American Express, Honda, Nescafe, Canon, LG and numerous other foreign brands are flashed on the screen along with shots of huge malls. The remaining images under the category 'Freedom' also construct 'free' India and insert 'free' Indians within the narrative of production and consumption. The images work to naturalize the narrative that India is 'free' to participate in a globalizing 
world characterized by a market economy and Indians are 'free' to fulfill their roles as global workers and consumers. Freedom within this context is an idea that has been simplified and whitewashed - stripped of its complexities and evacuated of its contentious histories-and repackaged as Brand Freedom.

As an IBEF overview of Brand India states, 'India today....has the fastest growing population of workers and consumers' (Brand Development, 2011, n.p.). The website also markets India's huge English-speaking, technology savvy workforce that reduces labor costs, thereby adding value to products and services. Furthermore, India's time zone in relation to that of the United States is highlighted as a huge advantage for Brand India. As Ramesh Jairam, former environment minister and a member of Rajya Sabha, India's upper house points out, 'You are working when America is sleeping and when America is working, you are still working' (quoted in Kapur, 2006, n.p.). The positioning of Indian population as 'human capital' - workers who can/must serve the round-the clock- needs of global capital so as to maintain India's high growth and its relevance in the global marketplace reifies the colonial power relations and the international divide of labor within a neoliberal world order. As Kapur (n.d.) has argued,

It was precisely this center-periphery relationship that enabled the Global North, following World War II, to transition into consumer economy by shifting production the third world, a process radicalized at the end of the $20^{\text {th }}$ century by new technologies and business practices which have made it possible to decentralize production while centralizing profits. (p. 14-15) 
Brand India valorizes the Indian 'global generation' (Kapur, n.d.) - a generation of young, mobile, consumers whose appetite for all brands global has fueled a consumer demand that is growing five times faster than the economy (Nilekani, 2006, n.p.). The images of well-dressed young Indians smiling and talking on their phones, shopping at malls and dancing at clubs is meant to indicate that New India has broken 'free' of its 'developing' status and is now 'emerging' as a nation that can and does consume the same brands as the modern, developed and advanced societies of Western Europe and America. However even as the freedom to consume is celebrated as a marker of India's entry into global modernity, it is a restricted freedom defined solely through the role played by the Indian global generation within the narratives of production and consumption. The global markets dominated by transatlantic capital reconceptualizes the Indian identity in purely market terms as 'human capital' - either as a worker providing low-priced labor or as a consumer contributing to high-end profits - thereby erasing their participation in other narratives and marginalizing their contesting subjectivities. The narrowing of the idea of freedom and the collapsing of democracy within market metrics reconstructs India, the brand nation, as a monolithic, single category, evacuated of its unsavory, unbranded past and stripped of its diversities and heterogeneities. Consequently the Indian global generation is also constructed as singular, monolithic subject and object - young, mobile consumer or young, conscientious worker thereby stripping them of their layered subjectivities and erasing the complexities of their material and lived realities. The construction of one, single India united in its goal for economic dominance works in tandem with the constitution of a single Indian people, also united in their quest for economic fulfillment, thereby erasing the differences, the distinctions and the divisions that exist within the country. Despite the normalization of the 'finally free' 
narrative by the nation branding discourse, not all Indians are 'free' to consume and not all Indians have the access to realize the dreams offered by the 'full' freedoms of neoliberalism. As Arundhati Roy (2009) has pointed out,

Today words like 'progress' and 'development' have become interchangeable with 'economic reforms', 'deregulation' and 'privatization'. 'Freedom' has come to mean 'choice'. Freedom has less to do with human spirit than with different brands of deodorant. The 'market' is a de-territorialized space where faceless corporations do business, including buying and selling 'futures'........ Those who cannot consume do not matter. (n.p.)

Indeed the Brand India narrative normalizes a 'nation on the move', naturalizes a market version of freedom and democracy and valorizes a consuming Indian identity. However, while the high glossed image of Brand India, created to project a corporatized narrative of the nation for the global economic gaze, celebrates the arrival of a neoliberal India on the global scene, it is an image and a construction that diminishes as much as it reveals. In the following section, I compare and contrast the two Indias - the one that is idealized by the Brand narrative and the other that is rejected.

\section{The 'Other' India}

The story of Brand India is a story of two Indias - the Brand(ed) India and the unbranded India. Brand India showcases a nation that is on the road to economic superstardom; a nation with 23 stock exchanges; 91 billion dollars companies; over US \$ 500 
billion in market capitalization and ever expanding and constantly consuming middle class (Media Print, 2006). Brand India highlights a 'dollar rich' nation where 54 percent of the super rich Indians account for 25\% of India's total GDP and 55 Indians featured on Forbes 2009 billionaires list (Kamdar, 2009, n.p.). Brand India valorizes a sanitized nation where a small but economically significant percentage of population enjoy a 'First World' lifestyle marked by conspicuous consumption, high life in gated communities and access to the best in health care, food and education (Ramesh, 2006).

On the other end of the spectrum is the unbranded India - which must be brought into modernity or simply perish. This is the India where more than 400 million people live on less than $\$ 1$ a day (ibid). This is the India where more than 100,000 farmers have committed suicide over the past decade - a decade characterized by Brand India's economic boom and stratospheric growth rates (Sainath, 2006). The unbranded India tells the story of a nation that ranks $127^{\text {th }}$ on the UNDP Human Development Index and where the per capita gross domestic product is just slightly higher than Sub Saharan Africa; where 2.5 million children die annually as a result of malnutrition (Kapur, 2006). The unbranded India is a 'Third World', under-developed India. For hundreds of millions of poor Indians, the brave new world of the1990s has meant the 'globalization of prices and Indianization of incomes' (Sainath, 2006, n.p.) Their descent into abject poverty and utter destitution is not a matter of concern for Brand India. Rather, it is a source of annoyance. Their lack of purchasing power and their inability to contribute to growth and productivity is a 'disappointment' for the brand nation, in a hurry to realize its economic dream (ibid). Commenting on the great divide that separate the two Indias, Arundhati Roy (2001) writes, 
It's as though the people of India have been rounded up and loaded onto two convoys of trucks (a huge big one and a tiny little one) that have set off resolutely in opposite directions. The tiny convoy is on its way to a glittering destination somewhere near the top of the world. The other convoy just melts into the darkness and disappears. (p. 188-189)

The India Everywhere campaign that lauched Brand India at the 2006 World Economic forum was degined to change perceptions about India. The campaign was designed to show the Davos delegates that the country was more than the world's back office and more than a just a hub for global outsourcing. The campaign wanted to tell a 'richer, fuller' story of a 'democractic, modern and contemporary' India - a India that was coming of age, an India that was moving upwards, an India that was on the road to economic glory. While the story of Brand India may be a 'credible' story of Indian business and Indian industry, of Indian workers and Indian consumers, it is an incredibly incomplete story of India, the nation.

\section{Conclusion}

The year, 1991 is celebrated by the Indian mainstream media and the Indian ruling elites as the year when the Indian population was granted 'full' freedom. It was 44 years after India became politically free that the nation got its 'first taste of economic freedom' (India Today, 2003, n.p.). As Nilekani (2008) points out, 'In entering its new age, India ended a long period of incomplete freedoms - a time of democratic rule but severe economic shackles' (p. 76). In this chapter I have shown how the launch of the New Economic Policy 
and the subsequent liberalization policies remodeled India the 'compassionate state' into India the 'competitive state'. The dismantling of the old economic regime and insertion of a neoliberal system of governance transformed India into a market-driven economy and a market-governed society. The promise of the market and its entrenchment within the dominant imaginary have thus become the defining lens through which India is constantly and consistently being reimagined.

I have discussed how 'New' India, now reimagined as a brand nation, began to grow at an exponential rate and the opening up of the Indian economy brought prosperity to a small but an economically significant percentage of the population. India is home to the largest growing consumer population and an educated, young labor force. For the citizens of Brand India, the logic of the market has meant higher standards of living, access to global brands and a future of 'endless possibilities'.

However, India when imagined as the 'world's largest free market democracy' conflates the idea of 'complete' freedom with economic freedom and reduces the idea of democracy to serve the needs of the marketplace. I have argued that the brand of freedom and democracy normalized within the narrative of Brand India is a freedom that has been stripped of its histories and its diversities and a democracy that been hollowed out to fit in with the demands of global capital. Brand India imagines a postcolonial nation that is evacuated of its colonial histories, its oppressive pasts and its contentious unglamorous presents. It glorifies a version of the nation that is palatable for global economic consumption and in the process erases and marginalizes all other interpretations, all other narratives, all other possibilities of imagining the nation. 
In my concluding chapter I point out that even as neoliberal India's imaginary is dominated by the corporatized version of India and the commodified interpretation of Indian identity, there are spaces of contestations and areas of disruptive possibilities where India is being imagined Otherwise. 


\section{CHAPTER SIX}

\section{Conclusion: Imagining India Otherwise}

The purpose of this thesis was to critically analyze the practice of nation branding as a dominant developmentalist strategy that facilitates the entry of a postcolonial nation into global modernity. Nation branding involves the application of marketing and public relations techniques to create, present and project a particular image of the nation and its people for the purposes of global trade and commerce. Nation branding experts argue that nation branding gives the country the much-needed edge to attract attention in an increasingly crowded global marketplace. For a poor, developing nation, this practice has been normalized and legitimized as an indispensable tool for economic empowerment and national wealth generation. By focusing on Brand India - postcolonial India's nation branding exercise - this thesis has attempted to rupture these universalizing claims and make visible the neocolonial underpinnings of the nation branding discourse. Drawing on Michel Foucault's work on governmentality, I have critiqued nation branding as technology of neocolonial governance, wherein postcolonial India's ascendancy on the world stage, its transformation into a 'booming' brand nation can only be understood through a language and within a frame work always-already constituted for us by our former colonial masters. I have argued that nation branding legitimizes and normalizes the economic rationale of western neoliberalism as a universal practice of good governance. However, when the practice is applied to a postcolonial nation, it works to reaffirm colonial logic and reinforce colonial power relations. By situating my critique within a postcolonial framework, I have attempted 
to unearth some of the asymmetrical power relations that have placed nation branding at the centre of the global developmentalist agenda.

India embarked upon a branding campaign to become relevant among the global political and business leaders at Davos - to show that the country had transformed from a nation that 'blathered on' about its '5000 years of culture' to a nation that could talk 'serious business' using the language of ROI (returns on investments) and EBITDA (earnings before interest, taxes, depreciation and amortization) (Knowledge@Wharton, 2006). India when imagined as brand is a nation that speaks in numbers: $\$ 500$ million market capitalization, $45 \%$ growth in the BPO sector, \$28 billion IT industry, 8\% GDP growth, 2.46 million graduates each year, 675 million eligible voters and the list keeps on going (India Information Pack, 2006). These impressive numbers keep the global capital interested and maintain the dominance of Brand India within the national imaginary. However, while India's chest-thumping debut at Davos may be a sign that the country has entered global modernity, it is also an indication that India still hasn't been granted a seat at the table. As Bowring (2006) has pointed out, 'the likes of Google paraded the obsequious inclinations of Western companies still dreaming of vast profits from the land of a billion people. But it was not accompanied by much willingness to accord the non-western world more say in the way the world is run...' (n.p).

Global leaders may have been photographed wearing traditional Indian headgear and Davos delegates may have turned out in large numbers to dance to the beats of Bollywood music. However they remained cautious about the 'New India Story' and reluctant to grant India a permanent place of reckoning within the global hierarchy of nations. They agreed that Brand India was a step in the right direction, but claimed that 'emerging' India still had a 
long way to go before it could stake a claim as an 'emerged' economy. Stephen Kobrin (2006) professor of management at Wharton School of business argued that India was still plagued by a 'lot of bureaucracy, a lot of controls, a lot of restrain, a lot of difficulty in establishing an enterprise and barriers in the way of entrepreneurship (Knowledge@ Wharton, n.p.).

India's continued pursuit of reforms to appease global capital and to remain competitive in a globalized world indicates that the Brand India narrative continues to define the dominant Indian imaginary. In an interview with Tehelka (2008), a weekly news magazine, India's finance minister, P. Chidambaram, the man who led the Dream Team at Davos 2006, laid out the expansion plans for Brand India. He declared,

My vision for a poverty-free India will be a India where a vast majority, something like $85 \%$ will eventually live in cities....In an urban environment it is easier and more efficient to provide water, electricity, education, roads, entertainment and security rather than in $6,00,000$ villages....to get rid of poverty in our lifetime, we need to work hard to sustain a growth rate of $9 \%$, moving up to $10 \%$. (Ray \& Chaudhury, n.p.)

As is evident, Chidambaram is speaking the language of numbers and articulating a vision that is informed by the western, neoliberal model of growth and development and premised on corporate interpretations of efficiency and productivity - ideas that dominate the thinking of a small but powerful minority of Indians. While the various techniques and rationalities put into place by the state work to create conditions that normalize this vision of 
modern India, there are spaces where the nation is being imagined in different terms and through a different language.

The Kondh people - the Dongria, Kutia and Jharania - of Eastern Orissa disagree with Chidambaram's version of efficiency and development. They disagree with the idea of a nation that is imagined through market metrics. They disagree with his vision of a predominantly urban India. The Kondhs live in the Niyamgiri Hills, far away from the world of Brand India marked by its quest for urbanization, modernization and consumption (Chamberlain, 2009). They live in a land characterized by its mountains, its streams and its forests. Their idea of a nation is one that will let them live according to the 'old way'. Their idea of efficiency is grounded in respecting the Niyam God - all through the slopes there are small shrines where they place offerings to the mountain from whatever they have taken from the forests (ibid). Their vision is to ensure that the mountain stays intact.

The Kondhs are engaged in a fight with the British mining giant, Vedanta Resources. The multinational corporation has been granted permission by the government to mine the Niyamgiri Mountain for the Bauxite that lies beneath its surface. The bauxite is worth billions and the multi-million dollar project is supposed to bring development to this extremely rural area (ibid). The Kondhs reject the number value placed on their mountain. They want the bauxite to stay buried so that their rivers may flow and their trees may bear fruit. The Kondhs took the fight ${ }^{26}$ to save Niyamgiri and preserve their way of life, to the Supreme Court of India and to the court of international public opinion. It is as much a fight for their mountain as it is for their right to imagine an India otherwise.

\footnotetext{
${ }^{26}$ India's Supreme Court gave the go-ahead for the mine, ruling in favor of Vedanta Resources. However in 2010, the Indian government blocked the project on environmental grounds (Rahman, 2010).
} 
Across India, there are protests and movements to resist the march of Brand India and its vision of an urbanized, modernized, consuming India. There is an armed 'Maoist' struggle waging in the Indian heartland to resist the 'eco-imperialist' exploitation of India's poorest by multinational corporations and pro-business government policies (Burke, 2010; Roy, 2009, 2010). The villagers of Jaitapur, along India's Konkan coast, are protesting the construction of a nuclear power plant on their land - a plant that will contaminate the waters where they fish and destroy the orchards where they grow mangoes (Bajaj, 2011). The farmers of Vidarbha are clamoring for their right to live from their land and recently, the Indian middle class took to the streets of India's urban cities to protest government corruption and political greed (Indian Express Service, 2011).

They imagine an India outside of the branding narrative. They imagine an India that is not dominated by numbers and market language. They imagine an India where the 'Old' is not discarded and the 'New' is not imposed. As Pramila Gawankar, the wife of Praveen Gawankar, the mango farmer leading the Jaitapur anti-nuclear protest said, 'It's nice to look out on the fields. We have the fish. We have the sea. We want for nothing' (quoted in Bajaj, 2011, n.p.). This thesis is written with the hope that the myopic vision of Brand India may be breached so as to enable the creating of conditions that allow for the possibility of Imagining Otherwise. 


\section{Bibliography}

Anderson, B. (1991). Imagined communities: Reflections on the origins and the spread of nationalism. London: Verso.

Anholt, S. (1999). Getting on the brandwagon. Impact, 3(4), 10-17.

Anholt, S. (2002). Foreword. Journal of Brand Management, 9(4/5), 229-239.

Anholt, S. (2003). Brand new justice: The upside of global branding. Oxford: ButterworthHeineman.

Anholt, S. (2006). Brand new justice: How branding places and products can help the developing world. Revised Edition. Oxford: Butterworth- Heineman.

Anholt, S. (2007). Competitive Identity: The new brand management for nations, cities and regions. Palgrave MacMillan.

Appiah, A. K., (2006). Cosmopolitanism: Ethics in a world of strangers. New York: W.W. Norton \&Co.

Appadurai, A. (1996). Modernity a Large: Cultural Dimensions of Globalization. Minneapolis: University of Minnesota Press.

Aronczyk, M. (2008). "Living the brand": Nationality, globality, and the identity strategies of nation branding consultants. International Journal of Communication, 2, 41-65.

Ashcroft, B., Griffiths, G., \& Tiffin, H. (2006). The post-colonial studies reader. London: Rutledge.

Bajaj, V. (2011, April 13). Resistance to Jaitapur nuclear plant grows in India. The New York Times. Retrieved from http://www.nytimes.com/2011/04/15/business/global/15nuke.html? r=2\&pagewanted=a $\underline{11}$

Barry, A., Osborne, T., \& Rose, N. (1996). Writing the history of the present. In A. Barry, T. Osborne \& N. Rose (Eds.), Foucault and political reason: liberalism, neo-liberalism and rationalities of government (pp. 1-17). Chicago: University of Chicago Press.

Behdad, A. (2005). On globalization again. In A. Loomba, S. Kaul, M. Bunzil, A. Butron \& J. Esty (Eds.), Postcolonial Studies and Beyond (pp. 62-79). Durham: N.C.: Duke University Press.

Betts, K. (2006, September 11). Art of the deal: Luxury's new lotus. Time Magazine. Retrieved from http://www.time.com/time/magazine/article/0,9171,1533536-1,00.html 
Bhagwati, J. (2004). In Defense of Globalization. New York: Oxford University Press.

Bhushan, R. (2003, November 17). Focus on brand India. The Hindu. Retrieved from http://www.hindu.com/biz/2003/11/17/stories/2003111700080200.htm

Bidwai, P. (2007). A davos lesson: Free market policies are unpopular. Transnational Institute. Retrieved from http://www.tni.org//archives/act/16187

Bowring, P (2006, January 29). At Davos, 'the world' means the West. The New York Times. Retrieved from http://www.nytimes.com/2006/01/29/opinion/29iht-edbowring.html

Bose, J. (2007, January 1). India Poised: Make 2007 the year of India. The Times of India. Retrieved from http://articles.timesofindia.indiatimes.com/2007-0101/india/27884634_1_indian-businessmen-real-story-global-stage

Boxer, S (2002, December 1). A new Poland: no joke. The New York Times Magazine. Retrieved from http://www.nytimes.com/2002/12/01/magazine/01PROCESS.html.

Brand Development. (2011). About us-Brand development. http://www.ibef.org. Retrieved 26 July 2011, from http://www.ibef.org/artdispview.aspx?cat_id=55\&art_id=29122

Brand India. (n.d.). Brand India - overview. http://www.ibef.org. Retrieved 15 March 2009, from http://www.ibef.org/brandindia/

Brand India Films. (n.d.) Imagination (video file). http://www.ibef.org. Retrieved 5 May 2009, from http://www.ibef.org/brandindia/Films.aspx

Brand India Films. (2006). India: Fastest growing free market democracy (video file). http://www.ibef.org. Retrieved 15 May 2009 from http://www.ibef.org/brandindia/Films.aspx

Burchell, G. (1993). Liberal government and the techniques of the self. Economy and Society, 22(3), 267-281.

Burke, J. (2010, May 28). Maoists in India: Long struggle for the landless poor. The Guardian. Retrieved from http://www.guardian.co.uk/world/2010/may/28/maoistsindia-naxalite-landless

Chakravarty, D. (2000). Provincializing Europe. Princeton: Princeton University Press.

Chamberlain, G. (2009, October 12). Vedanta versus the villagers: The fight for the sacred mountain. The Guardian. Retrieved from http://www.guardian.co.uk/business/2009/oct/12/vedanta-versus-the-villagers

Chatterjee, P. (1993). The Nation and its fragments: Colonial and postcolonial histories. Princeton, NJ: Princeton University Press. 
Chatterjee, P. (2005). The nation in heterogeneous time. Futures, 37, 925-942.

Dinnie, K. (2008). Nation branding: Concepts, issues, practice. UK: ButterworthHeinemann.

Domeisen, N. (2003). Is there a case for national branding? International Trade Centre, International Trade Forum, 1. Retrieved 8 May 2009, from http://www.tradeforum.org/news/fullstory.php/aid/534/Is_There_a_Case_for_National_ Branding .html

Fan, Y. (2005). Branding the nation: What is being branded? Journal of Vacation Marketing, 12(1), 5-14.

Fan, Y. (2008). Key perspectives in nation image: A conceptual framework for nation branding. Brunel Business School Research Papers. Retrieved from http://bura.brunel.ac.uk/handle/2438/1872.

Foucault, M. (1980). Two lectures. In C. Gordon (ed.), Power/Knowledge. (pp. 107-133). Brighton: Harvester.

Foucault, M. (1982). The subject and the power. In H. Dreyfus and P. Rabinow (Eds.), Michel Foucault: Beyond Structuralism and Hermeneutics (pp. 208-226). Brighton: Harvester.

Foucault, M. (1981). The order of discourse. In R. young (Ed.), Untying the text: A poststructuralist Reader (pp. 48-79). London: Routledge, Kegan and Paul.

Foucault, M. (1984). Preface to the History of Sexuality, Vol. II. In P. Rabinow (Ed.) The Foucault Reader (pp. 333-339). New York: Pantheon Books.

Foucault, M. (1991). Governmentality. In G. Burchell, C. Gordon \& P. Miller (Eds.), The Foucault Effect: Studies in Governmentality (pp. 87-104). Chicago: University of Chicago Press.

Foucault, M. (1991a). Question of Method. In G. Burchell, C., Gordon, C., \&. P. Miller (Eds.), The Foucault Effect: Studies in Governmentality (pp. 85-103). Chicago: University of Chicago Press.

Gandhi, L. (1998). Postcolonial theory: A cultural introduction. New York: Columbia University Press.

Gentleman, A. (2006). India wants the world to see it as it sees itself. The New York Times. Retrieved from http://www.nytimes.com/2006/10/26/world/asia/26ihtletter.3294437.html? r=1\&scp=1\&sq=nation\%20branding\%20india\&st $=$ cse 
Gertner, D. and Kotler, P. (2002). Country as brand, products and beyond: A place marketing and brand management perspective. Journal of Brand Management, 9 (4-5), 249-262.

Gibson-Graham, K. (1996). The end of capitalism (as we knew it): A feminist critique of political economy. Cambridge, MA: Blackwell.

Gilmore, F. (2002). A country-can it be repositioned? Spain- the story of country branding. Journal of Brand Management, 9(4-5), 281-293.

Gordon, C. (1991). Governmental rationality: an introduction, In G. Burchell, C. Gordon and P. Miller (Eds.), The Foucault Effect: Studies in Governmentality (pp. 1-51). Chicago: Chicago University Press.

Gulzar. (2007). India v/s India. Transcribed September February 9, 2009 from http://www.indiapoised.com/video2.htm.

Gumbel, P. (2005, May 29). Brand aid, not band aid. Time Magazine. Retrieved from http://www.time.com/time/magazine/article/0,9171,1066889,00.html

Hankinson, G. (2001). Location branding: A study in branding practices of 12 cities. Journal of Brand Management, 9(2), 127-142.

Hardt, M., \& Negri, A. (2000). Empire. Cambridge, Mass: Harvard University Press.

Hebbar, P. (2006, January 1). Dil mange more: As good as it gets. The Times of India. Retrieved from http://epaper.timesofindia.com/Default/Scripting/ArticleWin.asp?From=Archive\&Sourc $\underline{\mathrm{e}=\text { Page } \& \text { Skin }=\text { pastissues } 2 \& \text { BaseHref }=\text { TOIM } / 2006 / 01 / 01 \& \text { PageLabel=59\&EntityId }=\mathrm{Ar}}$ $\underline{05900 \& \text { ViewMode }=\text { HTML\&GZ }=\text { T }}$

Held, D., \& McGrew, A. (Eds.). (2003). The global transformation reader: An introduction to globalization debate. Second edition. Cambridge, UK. Polity.

Holmes, P. (2006, November 6). How India took Davos by Storm. Holmes Report. Retrieved from http://www.holmesreport.com/opinion-info/5441/How-Brand-India-Took-DavosBy-Storm.aspx.

Howard, S. (2011, July 20). Paris still seduces (for now) finds nation branding report. www.forbes.com. Retrieved from http://www.forbes.com/sites/sallyhoward/2011/07/20/paris-still-seduces-for-now-findsnation-branding-report/

IBEF Logo. (n.d.). IBEF-logo. http://www.ibef.org. Retrieved 10 April 2009, from http://www.ibef.org/AboutUs.aspx 
Idris, K., \& Hisamitsu, A. (2006). Cultural heritage, creativity and national pride. In The Intellectual Property-Conscious Nation: mapping the Path from Developing to Developed (pp. 77-96). World Intellectual Property Organization.

Independent Evaluation Group. (n.d.). Structural adjustment in India. http://www.worldbank.org. Retrieved from http://lnweb90.worldbank.org/oed/oeddoclib.nsf/b57456d58aba40e585256ad400736404 /0586cc45a28a2749852567f5005d8c89?OpenDocument

India Brand Equity Foundation. (n.d.). Brand India. Retrieved 20 August 2010, from http://www.ibef.org/brandindia

India Information Pack. (2006). India. Davos 2006. January 25-29. http://www.imdiaeverywhere.com. Retrieved 5 September 2010, from http://www.indiaeverywhere.com/pressinfo.aspx

India Today (2003, August 18). Liberalisation- second independence. India Today. Retrieved from http://archives.digitaltoday.in/indiatoday/20030818/56-46.html

Indian Express Service. (2011, August 18). Protests across city in support of Anna Hazare. Indian Express. Retrieved from http://www.indianexpress.com/news/protests-acrosscity-in-support-of-anna-haza/833468/

International Trade Centre. (2002). Executive Forum 2002. Managing Competitive Advantage: The Values for national Strategy. Retrieved 8 May 2009 from http://www.intracen.org/exec/forum/ef2002/programme.htm

Jana, R. (1997). Winds, rivers and rain: An interview with Arundhati Roy. Salon. Retrieved from http://www.salon.com/sept97/00roy.html

Jansen, S. C. (2008). Designer nations: Neo-liberal nation branding - brand Estonia. Social Identities, 14(1), 121-142.

Kamdar, M. (2009, November 24). Outsourcing India: For Obama and Singh, democracy means business. The Huffington Post. Retrieved from http://www.huffingtonpost.com/mira-kamdar/outsourcing-india-for-oba b 365781.html

Kaneva, N. (2011). Nation branding: towards an agenda for critical research. International Journal of Communication, 5, 117-141.

Kapur, J. (2003). Free market, branded imagination- Harry Potter and the commercialization of children's culture. Jump Cut, A Review of Contemporary Media, 46. Retrieved from http://www.ejumpcut.org/archive/jc46.2003/kapur.potter/text.html

Kapur, J. (2006). India Inc: The nation on sale in the new empire. State of Nature, Summer, 2006. Retrieved from http://www.stateofnature.org/indiaInc.html 
Kapur, J. (n.d.). Brand India's largest sale: the new global generation. Manuscript submitted for publication.

Klein, N. (2000). No Logo: taking aim at the brand bullies. Canada: Random House.

Klein, N. (2002). The spectacular failure of brand USA. www.naomiklein.org. Retrieved from http://www.naomiklein.org/articles/2002/03/spectacular-failure-brand-usa.

Knowledge@Wharton. (2006, February 22). Delhi in Davos. How India built its brand at the world economic forum. http://knowledge.wharton.upeen.edu/Retrieved from http://knowledge.wharton.upenn.edu/article.cfm?articleid=1394.

Kripalani, M. (2006, January 23). Davos days, Bollywood nights. Bloomberg Businessweek. Retrieved from http://www.businessweek.com/bwdaily/dnflash/jan2006/nf20060123 $5900 \mathrm{db} 016 . \mathrm{htm}$

Kripalani, M. (2006a, January 30). Selling India Inc. at Davos. Bloomberg Businessweek. Retrieved from http://www.businessweek.com/bwdaily/dnflash/jan2006/nf20060130_4381_db032.htm

Landler, M. (2006, January 26). India launches a charm offensive. The New York Times. Retrieved from http://www.nytimes.com/2006/01/26/business/worldbusiness/26ihtdavos.html? r=1.

Loomba, A. (2005). Colonialism/Postcolonialism. London: Routledge.

Loomba, A., Kaul, S., Bunzil, M., Burton, A., and Esty, J. (Eds.). (2005). Postcolonial studies and beyond. Durham (N.C.): Duke University Press.

Masterclasses. (n.d.). Masterclasses. http://www.simonanholt.com. Retrieved 6 July 2011, from http://www.simonanholt.com/Masterclasses/masterclasses-introduction.aspx

Media Outdoor. (2006). Inside Zurich airport - Arrival dock A. http://www.indiaeverywhere.com. Retrieved 9 March 2009, from http://www.indiaeverywhere.com/adgallery.aspx

Media Print. (2006). India- the fastest growing free market democracy: The campaign, print. http://www.indiaeverywhere.com. Retrieved 9 March, 2009, from http://www.indiaeverywhere.com/print.aspx

Miller, P., \& Rose, N. (1990). Governing economic life. Economy and Society, 19(1), 1-31

Mills, S. (2003). Michel Foucault. London: Routledge.

MSNBC. (2006, January 28). India the darling of world economic forum. www.msnbc.msn.com. Retrieved from 
http://www.msnbc.msn.com/id/11076024/ns/business-world_business/t/india-darlingworld-economic-forum/.

Mosco, V. (1996). The political economy of communication: Rethinking and renewal. Thousand Oaks, Ca: Sage.

Nilekani, N. (2006). Letter by chairman, India Everywhere to delegates. http://www.indiaeverywhere.com. Retrieved 18 November 2010, from http://www.indiaeverywhere.com/DreamIndia.aspx

Nilekani, N. (2008). Imagining India: the idea of a renewed nation. New Delhi: The Penguin Press.

Olins, W. (1999). Trading Identities: Why countries and companies are taking on each others' roles. London: Foreign Policy Centre.

Olins, W. (2002). Branding the nation- the historical context. Journal of Brand Management, 9 (4-5), 241-248.

Olins, W. (2003). Wally Olins. On brand. London/New York: Thames \& Hudson.

O’Malley, P., Weir, L., \& Shearing. C. (1997). Governmentality, criticism, politics. Economy and Society, 26(4), 501-517.

Papadopoulos, N. and Heslop, L. (2002). Country equity and country branding: Problems and prospects. Journal of Brand management, 9 (4-5), 294-315.

Press Release. (2006, January 23). Largest ever participation at the world economic forum's annual meeting in January 2006. http://www.indiaeverywhere.com. Retrieved 15 November 2010, from http://www.indiaeverywhere.com/pressrelease.aspx

Press Release. (2006a, January 25). India's growth reflects growing private-public partnership. http://www. indiaeverywhere.com. Retrieved 15 November 2010, from http://www.indiaeverywhere.com/pressrelease.aspx

Press Release. (2006b, January, 28). Rural infrastructure, employment, FDI key to $8 \%$

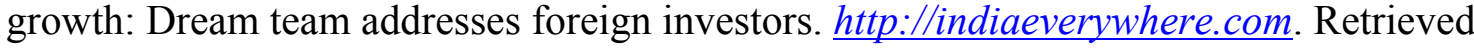
15 November 2010, from http://www.indiaeverywhere.com/pressrelease.aspx

Press Release. (2006c, January 29). World Rocks to Indian Tunes at Grand Soiree. http://www.indiaeverywhere.com. Retrieved 10 October 2010, from http://www.indiaeverywhere.com/pressrelease.aspx

Preston, P. (1999, November, 15). Branding is cool. Its Tony Blair's favourite pastime. The Guardian. Retrieved from http://www.guardian.co.uk/politics/1999/nov/15/labour.labour1997to99 
PTI. (2010, March 17). IMF pegs India's growth rate at 8\% in 2010-11. The Times of India. Retrieved 4 July 2011, from http://articles.timesofindia.indiatimes.com/2010-0317/india-business/28141877_1_imf-pegs-fiscal-deficit-indian-economy

Purie, A. (2006). Hype and hardsell. India Today. Retrieved from http://www.indiatoday.com/itoday/20060213/cover.html

Rahman, M. (2010). India blocks Vedanta mine on Dongria-Kondh tribe's sacred hill. The Guardian. Retrieved from http://www.guardian.co.uk/business/2010/aug/24/vedantamining-industry-india

Randeep, R. (2006, April 5). A tale of two Indias. The Guardian. Retrieved from http://www.guardian.co.uk/world/2006/apr/05/india.randeepramesh2/print.

Ray, S., \& Chaudhury, S. (2008). My vision is to get $85 \%$ of India into cities. Telhelka. Retrieved from http://www.tehelka.com/story main39.asp?filename=Ne310508cover_story.asp

Rendon, J (2003, November 23). When nations need a little marketing. The New York Times. Retrieved from http://www.nytimes.com/2003/11/23/business/business-when-nationsneed-a-little-marketing.html?scp=1\&sq=nation+branding \&st=nyt

Risen, C. (2005). Branded Nations. New York Times Magazine. Retrieved from http://www.nytimes.com/2005/12/11/magazine/11ideas1-5.html?_r=1

Rose, N. (1996). Governing 'advanced' liberal democracies. In A. Barry, T. Osborne \& N. Rose (Eds.), Foucault and Political Reason: Liberalism, Neo-liberalism and Rationalities of Government (pp. 37-64). Chicago: University of Chicago Press).

Rose, N. (1999). Powers of freedom: Reframing political thought. Cambridge: Cambridge University Press.

Roy, A. (2001). The ladies have feelings so shall we leave it to the experts? In The Algebra of Infinite Justice (pp. 188-215). New Delhi: Penguin Books.

Roy, A. (2009). Democracy's failing light. Outlook India. Retrieved from http://www.outlookindia.com/article.aspx?250418

Roy, A. (2010). Walking with the comrades. Outlook India. Retrieved from http://www.outlookindia.com/article.aspx?264738

Roy, S. (2007). Beyond belief: India and the politics of postcolonial nationalism. Durham and London: Duke University Press.

Said, E. (2003). Orientalism. New York: Vintage Books. 
Sainath, P. (2006, January 29). Manufactured reality. People's Democracy, XXX (5). Retrieved from http://pd.cpim.org/2006/0129/01292006_p\%20sainath.htm

Scott, D. (1999). Refashioning futures: criticism after postcoloniality. Princeton: Princeton University Press.

Sengupta, A. (2006). Showtime everywhere at Davos 2006.

http://www.exchange4media.com. Retrieved 13 January 2011, from

http://www.exchange4media.com/viewpoint/viewpoint.asp?view $\mathrm{id}=70$

Singh, M. (1991, July 24). Budget 1991-92 speech of Shri. Manmohan Singh, minister of finance. Retrieved 5 July 2011, from indiabudget.nic.in/bspeech/bs199192.pdf.

Singh, T. (2006, February 4). Another India in Davos. Deccan Herald. Retrieved from http://archive.deccanherald.com/deccanherald/feb42006/panorama144334200623.asp

Stiglitz, J. (2002). Globalism's Discontents. Global Policy Forum. Retrieved from http://www.globalpolicy.org/component/content/article/162/27705.html

The Economist. (2006, November 9). National branding: a new sort of beauty contest. Retrieved from http://www.economist.com/world/international/displaystory.cfm?story_id=E1_RTQSD $\underline{\mathrm{VV}}$

The Economist. (2011, July 21). One more push. Retrieved from http://www.economist.com/node/18988536.

Thobani, S. (2007). Exalted Subjects: Studies in the making of race and nation in Canada. Toronto: University of Toronto Press.

Times of India. (2005, June 26). Times now masthead of the world. Times of India. Retrieved from http://timesofindia.com/articlshow/1152489.cms.

Tripathi, S. (2006, June 13). Escaping the 'hindu rate of growth'. The Guardian. Retrieved from http://www.guardian.co.uk/commentisfree/2006/jun/13/escapingthehindurateofgro

United Nations Global Impact. (2011). Country branding \& partnership: Creating and managing country brand value and partnerships with business. Fourth United Nations Conference on Least Developed Countries. Retrieved from http://www.unglobalcompact.org/NewsAndEvents/LDC_IV/forum_events.html

Van Ham, P. (2001). The rise of the brand state: the postmodern politics of image and reputation. Foreign Affairs, 80 (5), 2-6.

Van Ham, P. (2008). Place Branding: The state of the art. The Annals of the American Academy of Political and Social Science, 61(1), 126-149. 
Varshney, A. (2007). India's democratic challenge. Foreign Affairs, 86(2), 93-106.

Volcic, Z. (2008). Former Yugoslavia on the world wide web: Commercialization and branding of nation-states. The International Gazette, 70(5), 395-413.

WIPO Magazine. (2005, July). IP, nation branding and economic development. WIPO Magazine, 4. Retrieved from http://www.wipo.int/wipo_magazine/en/2005/04/article_0001.html

Wired. (1999, October 10). Rebranding Britannia. http://www.wired.com. Retrieved from http:/www.wired.com/wired/archive/6.10/netizen.html?pg=3

Zakaria, F. (2006, May 5). India rising. Newsweek Magazine. Retrieved from http://www.newsweek.com/2006/03/05/india-rising.html 